\title{
Extracellular Vesicles from Red Blood Cells and Their Evolving Roles in Health, Coagulopathy and Therapy
}

\author{
Kiruphagaran Thangaraju ${ }^{1,+}$, Sabari Nath Neerukonda ${ }^{2,3,+}\left(\mathbb{D}\right.$, Upendra Katneni ${ }^{1, *(1)}$ and Paul W. Buehler ${ }^{1,4}$ \\ 1 Center for Blood Oxygen Transport and Hemostasis, Department of Pediatrics, University of Maryland \\ School of Medicine, Baltimore, MD 21201, USA; kthangaraju@som.umaryland.edu (K.T.); \\ pbuehler@som.umaryland.edu (P.W.B.) \\ 2 Department of Animal and Food Sciences, University of Delaware, Newark, DE 19716, USA; \\ nnvsnath@udel.edu \\ 3 Center for Biologics Evaluation and Research, U.S. Food and Drug Administration, \\ Silver Spring, MD 20993, USA \\ 4 Department of Pathology, University of Maryland School of Medicine, Baltimore, MD 21201, USA \\ * Correspondence: ukatneni@som.umaryland.edu; Tel.: +1-4107067088 \\ + The authors contributed equally to this work.
}

Citation: Thangaraju, K.;

Neerukonda, S.N.; Katneni, U.; Buehler, P.W. Extracellular Vesicles from Red Blood Cells and Their Evolving Roles in Health, Coagulopathy and Therapy. Int. J. Mol. Sci. 2021, 22, 153

https://dx.doi.org/10.3390/ ijms22010153

Received: 2 December 2020

Accepted: 22 December 2020

Published: 25 December 2020

Publisher's Note: MDPI stays neutral with regard to jurisdictional claims in published maps and institutional affiliations.

Copyright: () 2020 by the authors. Licensee MDPI, Basel, Switzerland. This article is an open access article distributed under the terms and conditions of the Creative Commons Attribution (CC BY) license (https: / / creativecommons.org/ licenses/by/4.0/).

\begin{abstract}
Red blood cells (RBCs) release extracellular vesicles (EVs) including both endosomederived exosomes and plasma-membrane-derived microvesicles (MVs). RBC-derived EVs (RBCEVs) are secreted during erythropoiesis, physiological cellular aging, disease conditions, and in response to environmental stressors. RBCEVs are enriched in various bioactive molecules that facilitate cell to cell communication and can act as markers of disease. RBCEVs contribute towards physiological adaptive responses to hypoxia as well as pathophysiological progression of diabetes and genetic non-malignant hematologic disease. Moreover, a considerable number of studies focus on the role of EVs from stored RBCs and have evaluated post transfusion consequences associated with their exposure. Interestingly, RBCEVs are important contributors toward coagulopathy in hematological disorders, thus representing a unique evolving area of study that can provide insights into molecular mechanisms that contribute toward dysregulated hemostasis associated with several disease conditions. Relevant work to this point provides a foundation on which to build further studies focused on unraveling the potential roles of RBCEVs in health and disease. In this review, we provide an analysis and summary of RBCEVs biogenesis, composition, and their biological function with a special emphasis on RBCEV pathophysiological contribution to coagulopathy. Further, we consider potential therapeutic applications of RBCEVs.
\end{abstract}

Keywords: red blood cells; extracellular vesicles; exosomes; microvesicles; microparticles; cell-to-cell communication; homeostasis; coagulopathy

\section{Introduction}

Extracellular vesicles (EVs) are a heterogenous population of membrane-delimited organelles released into the extracellular milieu by eukaryotic and prokaryotic cells [1]. The first EV-like particles were suggested by Edward G. Horder in the late 1800s [2]. In 1967, Peter Wolf identified vesicles derived from activated platelets and termed them "platelet dust" [3,4]. The first description of erythropoietic cell origin EVs was provided by Johnstone et al. in 1987 using in vitro cultured sheep reticulocytes [4]. EVs were reported to be present in blood and other body fluids including saliva, breast milk, urine, semen, sputum, cerebrospinal fluid, and nasal fluid [5-7]. Under both physiological and pathological conditions, various cell types including endothelial cells, lymphocytes, dendritic cells, mast cells, platelets, leukocytes, erythrocytes, cancer cells, hematopoietic cells, neurons, and oligodendrocytes were reported to secrete EVs $[1,8,9]$.

Originally thought of as a means to dispose of cellular waste products, EVs are now regarded as vehicles of intercellular communication that impact several physiolog- 
ical and pathological processes [8,9]. Despite their heterogeneity, EVs overlap in size, density, and content, which poses a significant technical challenge for separation and characterization of distinct EV subpopulations [10]. Nevertheless, extensive characterization has led to a broad categorization of EVs on the basis of size ( $<200 \mathrm{~nm}$ (small EVs), or $>200 \mathrm{~nm}$ (medium/large EVs)) or density (low, middle, high), biochemical composition (e.g., CD63+/CD81+-EVs, Annexin A5+ EVs, etc.) and cellular origin (e.g., oncosomes of tumor cells) or treatment condition (e.g., hypoxic EVs) [10]. Small EVs include exosomes whose size range falls between 50 and $150 \mathrm{~nm}$ in diameter whereas medium/large EVs comprise microvesicles and apoptotic bodies with size ranges $<1 \mu \mathrm{M}$ and $1-5 \mu \mathrm{m}$, respectively [10].

Exosomes are generated along the endosomal pathway after the first step of plasma membrane (PM) invagination to form early endosomes [11]. Early endosomes mature into late-sorting endosomes, which eventually become multivesicular bodies (MVBs) bearing intra-luminal vesicles (ILVs). ILVs are generated upon inward invagination of endosomal structures generating membrane-derived MVBs. Newly formed MVBs can either undergo targeted degradation after fusion with lysosomes and autophagosomes, or fuse with PM to release the ILVs as exosomes (Figure 1) [12-16]. The endosomal sorting complex required for transport (ESCRT) complexes primarily mediate inward budding of ILVs into MVBs and concomitantly the exosome cargo selection process [12,17]. Exosome release and uptake is a constitutive homeostatic process among many cell types except mature RBCs which lack the endocytic machinery $[4,18]$. Microvesicles and apoptotic bodies are generated upon PM exvagination and apoptotic blebbing, respectively (Figure 1) $[19,20]$. In the current review, small- and large-sized vesicles from RBCs are referred to exclusively as EVs since they are not yet fully characterized into independent categories.

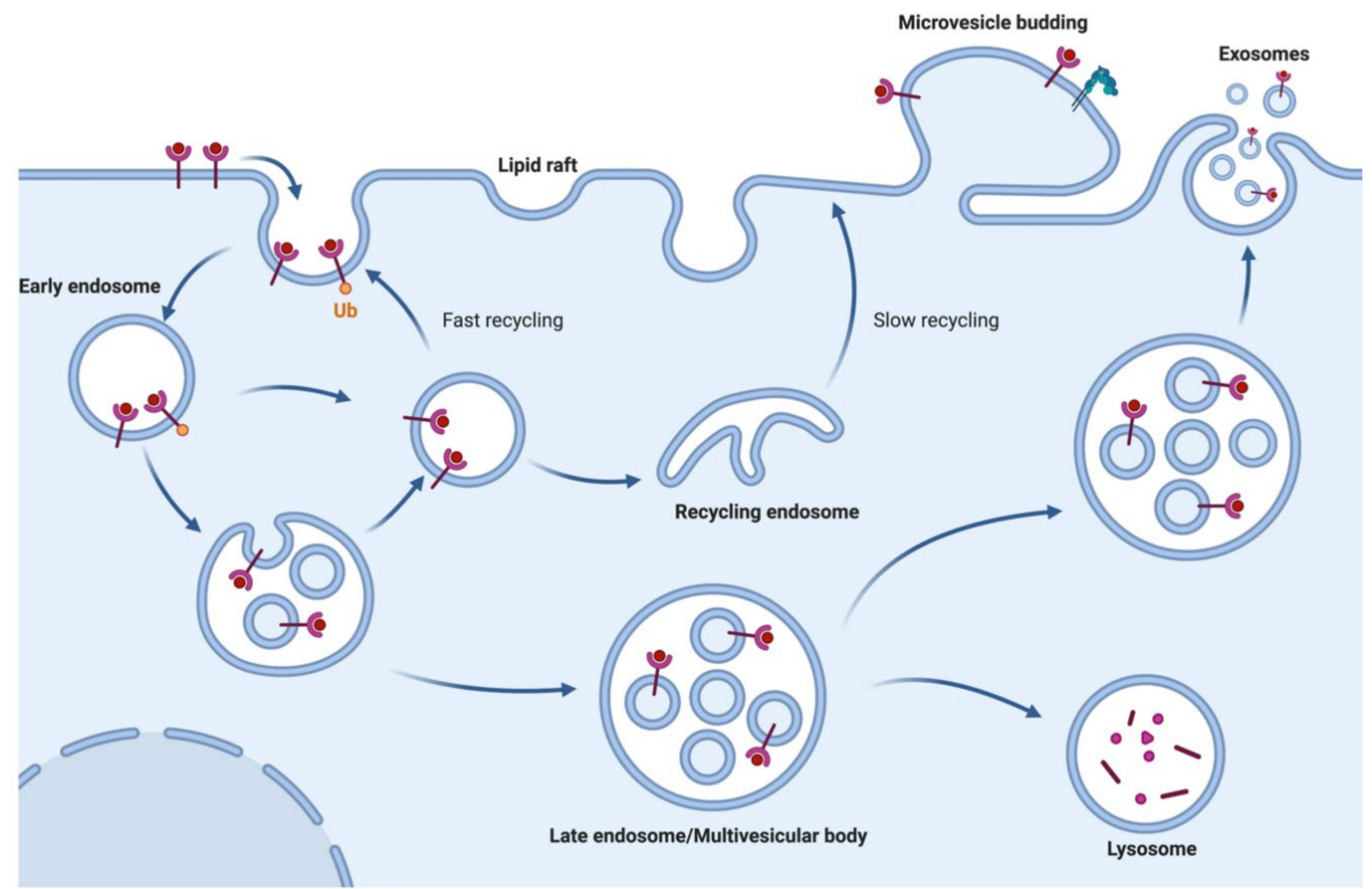

Figure 1. Biogenesis of extracellular vesicles (EVs; exosomes and microvesicles): EVs are broadly classified into two categories: exosomes and ectosomes or microvesicles. Exosomes demonstrate a size range between 40 to $150 \mathrm{~nm}$ and are generated through a process that involves double invagination of the endosomal membrane to form multivesicular bodies containing intraluminal vesicles. This process is followed by fusion of the multivesicular bodies to the plasma membrane to produce exosomes. By contrast, ectosomes (i.e., microvesicles) and large vesicles are generated by outward budding of the plasma membrane with a size range of 50 to $1000 \mathrm{~nm}$ in diameter. (Figure created with BioRender.com). 


\section{EV Biogenesis}

\subsection{Exosome Biogenesis}

In nucleated cells, EVs are defined either as exosomes or MVs and each have distinct subcellular origins. Exosome biogenesis was initially described in yeast where four ESCRT complexes (ESCRT-0, -I, -II and -III), along with their protein partners (e.g., ALIX, VPS34), sequentially perform cargo selection, inward membrane invagination, and scission, causing exosomes or ILV biogenesis [21]. ESCRT0 initially recruits ESCRTI complex in order to cluster ubiquitinated protein cargo on endosomal membrane microdomains. Upon complexing with ESCRTII subunits, both ESCRT-I and -II complexes initiate the invagination, while ESCRTII recruits the ESCRTIII complex into the neck of nascent ILVs to mediate budding and vesicle scission [22-26]. An additional pathway of ILV biogenesis that occurs in an ESCRTIII subunit (CHMP4) dependent manner is mediated by syndecan-syntenin-ALIX complex [27].

Alternatively, exosomes can also be formed in an ESCRT-independent manner [28-30]. Exosome formation is still evident in cells depleted of all four ESCRT complexes [28]. ESCRT-independent mechanisms of exosome biogenesis involve generation of membrane subdomains through the ceramide or tetraspanin protein family [29-31]. Neutral type II sphingomyelinase hydrolyses sphingomyelin to ceramide, which in turn coalesces smaller membrane microdomains into larger domains that drive domain-induced ILV budding [30]. However, ceramide is sequentially metabolized into sphingosine 1-phosphate (S1P), which permits cargo sorting into ILVs by continuous activation of inhibitory G $\left(\mathrm{G}_{\mathrm{i}}\right)$-protein-coupled S1P receptor [32]. The tetraspanin family of proteins (CD9, CD63, CD81, and CD82) generate budding microdomains by forming clusters and membrane platforms between each other and with various other transmembrane and cytosolic proteins [29,31]. Among tetraspanins, CD63 is a bona fide exosomal marker that was demonstrated to be involved in endosomal sorting, ILV cargo sorting, and exosome biogenesis in melanocytes [13,29], melanoma cells [33], and fibroblasts [34], respectively. Furthermore, tetraspanins are also involved in routing cargo, such as integrins to multivesicular endosomes, indicating their role in cargo sorting apart from exosome biogenesis [35].

Exosomes are packaged in endosomes during the process of erythropoiesis from hematopoietic stem cells through erythropoietin-dependent cellular maturation ending in erythroblasts formation. By the time iron dependent hemoglobin $(\mathrm{Hb})$ synthesis begins in the process of reticulocyte maturation to erythrocytes, exosomes are defined and packaged [36-38]. Circulating reticulocytes and erythroid precursors contain components of ESCRT complexes required for exosome biogenesis. Proteomic analysis of exosomes derived from human cord blood reticulocytes as well as exosomes derived from human and murine reticulocytes has identified ESCRT proteins involved in MVB biogenesis. These proteinsincluding Hrs (ESCRT-0), TSG101 (ESCRT-I), Alix (ESCRT-II), and CHMP4B (ESCRT-III)highlight identical mechanisms of exosome biogenesis as described above $[39,40]$. These particular ESCRT proteins were also identified in the human RBC proteome; however, their RBC specific roles in the process of vesiculation remains to be determined [41] and there remains a possibility that they simply represent carry over of EVs derived from nucleated cells.

\section{2. $M V$ Biogenesis}

MV biogenesis and release is an integral part of RBC physiology that is coupled with $\mathrm{RBC}$ maturation and ageing that facilitates the timely disposal of damaged RBC components, which otherwise may trigger unwanted hemostatic and immunological reactions [42]. Microvesicle release during RBC maturation is a mechanism to dispose of unwanted proteins, and to alter the cell volume to surface area to enable membrane remodeling [37]. MVs containing acetylcholinesterase, membrane proteins (e.g., transferrin receptor), glucose membrane transporters (e.g., GLUT-1), and amino acid transporters (e.g., excitatory amino acid transport, EAAT family) might contribute to RBC membrane remodeling during maturation [37]. MV shedding by ageing RBCs contributes to the loss of $\mathrm{Hb}$ (approximately 
$20 \%$ ) and cell membrane with a concomitant decrease in cell volume and an increase in cell density [43-45]. The $\mathrm{Hb}$ composition of RBC MVs is enriched with irreversibly modified species ( $\mathrm{HbA} 1 \mathrm{c}$ and $\mathrm{HbA1e}$ ) that are typically identified in senescent RBCs in dense fractions $[44,46]$. RBC MV biogenesis involves profound alterations in the anatomy of RBC membrane that is made of phospholipids and several integral membrane proteins present as macromolecular complexes centered on the anion-exchange channel, band $3[47,48]$. The membrane cytoskeleton laminating the inner membrane surface comprises cytoskeletal proteins, spectrin [49,50], actin [51] and its associated proteins (tropomyosin, tropomodulin, adducin, and dematin) [52-55], protein 4.1R [56,57], and ankyrin [47]. Band 3 macromolecular complexes are dynamic with bound and unbound integral membrane proteins (e.g., CD44, CD47, glycophorins) or peripheral membrane proteins (e.g., glycolytic and redox enzymes) [41] (Figure 2). Proteomic and immunoblot analyses of RBC MVs from the blood plasma of healthy individuals indicate identification of membrane or cytoskeletal proteins, aggregated specifically with band 3 and actin, absent spectrin and ankyrin [46]. Furthermore, RBC MVs contain elevated concentrations of enzymes involved in redox homeostasis, including glutathione $\mathrm{S}$ transferase, thioredoxin, and peroxiredoxin- 1 and -2 in vesicles compared to erythrocyte membranes [46]. In addition, the MV membrane contains removal signals such as phosphatidylserine (PS) and immunoglobulins (Igs) [46], whereas RBC membrane is highly enriched in proteasome subunits and ubiquitin [46]. These contents highlight several putative upstream processes, including, but not limited to, $\mathrm{Hb}$ damage, protein oxidation, and senescence-associated degradation of band 3-cytoskeletal ankyrin association as predominant triggers for MV generation [46]. Dismantling band 3-ankyrin binding eventually relieves the connection between the cytoskeleton and the lipid bilayer, resulting in exvagination and vesiculation [42,58]. These processes are evident in hemoglobinopathies including sickle cell anemia (SCA) and thalassemia intermedia (TI) where increased levels of circulatory MVs correlate with plasma $\mathrm{Hb}$ concentrations and accumulation of degraded $\mathrm{Hb}$ [59]. Similarly, in TI patients, $\alpha$ or $\beta$ oxidation form unstable membrane-bound hemichromes, which facilitate band 3 oxidation by the release of free iron radicals [60]. Oxidized band 3 dimers are subject to phosphorylation by p72Syk kinase on Tyr 8 and 21 residues of band 3 cytoplasmic domain to result in the weakening of its association with cytoskeleton and greater lateral mobility causing subsequent aggregation [60]. Aggregated band 3 and hemichromes are released into MVs. Aggregated band 3 is also bound by anti-band 3 Igs that subsequently undergo phagocytic removal. Consistent with this process, proteomic analyses of TI MVs identified denatured $\alpha$-globin, Igs and a number of proteins involved in redox homeostasis (e.g., HSP90, HSP70, catalase, and peroxiredoxin-2) [60]. The presence of PS, C3, and Igs facilitate the removal of MVs by liver Kupffer cells and spleen red pulp macrophages [61]. The presence of glycosylphosphatidylinositol (GPI)-anchored complement-inhibiting proteins CD55 and CD59 on MV surfaces may prevent unwanted activation of complement during vesicle removal, if functionally configured [42].

Alterations in phospholipid distribution in the lipid bilayer suggest another mechanism of RBC MV biogenesis. RBC membrane integrity is maintained by four major classes of phospholipids that are asymmetrically segregated on opposite leaflets of the bilayer (Figure 2). The choline-based phospholipids, sphingomyelin (SM), and phosphatidylcholine (PC) are enriched in the outer leaflet, whereas the primary amine-based phospholipids, phosphatidylethanolamine (PE), and phosphatidylserine (PS) are enriched on the inner cytoplasmic leaflet with PS displaying an absolute distribution [62]. This lipid asymmetry is maintained by phospholipid transporter enzymes known as flippases (inward), floppases (outward), and scramblases (bidirectional) [63]. Under resting conditions, when the cytoplasmic $\mathrm{Ca}^{2+}$ concentration is low, flippases internalize negatively charged PS whereas floppase and scramblase remain inactive. Activation or inactivation of phospholipid transporter enzymes by triggers causing oxidation or $\mathrm{Ca}^{2+}$ influx was known to induce vesiculation [64-66] (Figure 2). 


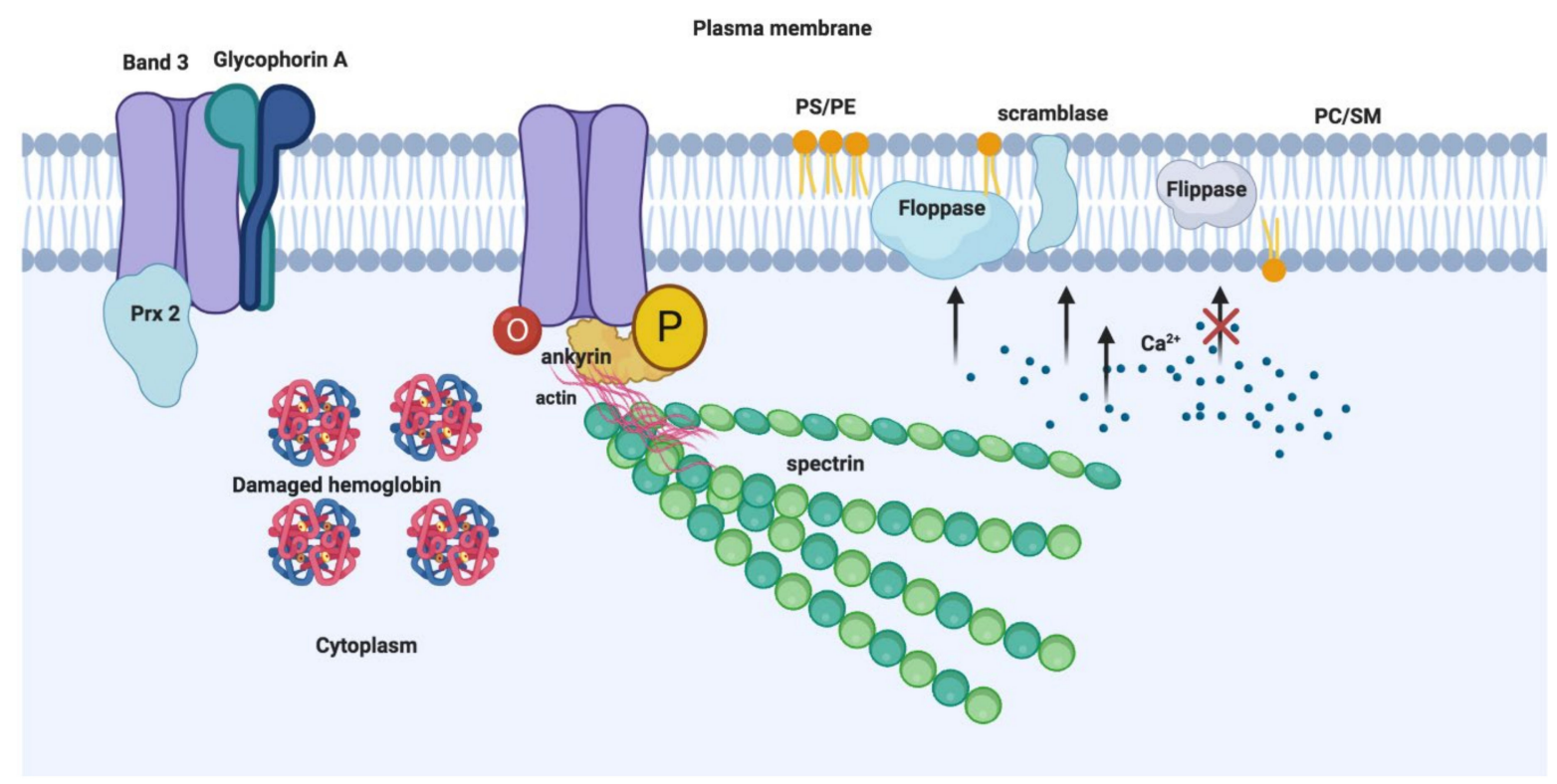

Figure 2. Mechanisms of RBC-MV biogenesis: MV generation on RBC membrane is predominantly triggered by damaged hemoglobin, protein oxidation, and senescence-associated degradation of band 3-cytoskeletal ankyrin association which result in evagination and vesiculation. Another mechanism involves the alterations in phospholipid distribution in lipid bilayer. Enzymes such as scramblase, calpain, and proteases are activated by oxidative damage or $\mathrm{Ca}^{2+}$ influx via nonspecific cation channels leading to inhibition of flippase and phosphatidylserine externalization, cytoskeletal proteolytic degradation, and band 3 aggregation, resulting in vesiculation. Peroxiredoxin 2 (Prx-2) binding to N-terminal cytoplasmic domain of band 3, phosphorylation $(\mathrm{P})$ and oxidation $(\mathrm{O})$ of band 3 are also indicated [67]. (Figure created with BioRender.com).

$\mathrm{Ca}^{2+}$ influx via nonspecific cation channels promotes the activation of calpain protease and scramblase and inhibits flippase leading to PS externalization, cytoskeletal proteolytic degradation and band 3 aggregation, all of which promote RBC membrane vesiculation $[63,68]$. Accordingly, incubation of RBCs with $\mathrm{Ca}^{2+}$ ionophore A23187, lysophosphatidic acid (LPA) or phorbol-12-myristate-13-acetate (PMA) to elevate intracellular $\mathrm{Ca}^{2+}$ concentration results in PS externalization, promoting the release of MVs, while incubation with a scramblase specific inhibitor (R5421) to prevent PS externalization significantly limits the release of MVs [65]. Notably, $\mathrm{Ca}^{2+}$ and A23187 incubation with erythrocytes also promotes co-release of nanovesicles (NVs), sized 60nm in diameter [69], whereas MVs are specifically enriched for lipid raft protein stomatin, raft proteins, synexin, and sorcin were observed in both MVs and NVs. Therefore, $\mathrm{Ca}^{2+}$ dependent vesicle release is a raft-based process. These studies do stress an important role for $\mathrm{Ca}^{2+}$ in the liberation of MVs or NVs from RBCs; however, non $\mathrm{Ca}^{2+}$ dependent pathways are also observed [65,70,71]. Specifically, limiting oxidative stress by the addition of small molecule antioxidants (e.g., ascorbic acid) during blood banking conditions reduces MV release over the time course of storage and also attenuates alloimmunogenicity in murine models of transfusion [72].

Different from RBCs, several mechanisms of MV biogenesis are defined in nucleated cells. Arrestin-domain-containing protein 1 (ARRDC1) -mediated microvesicles (ARMMs) of $\sim 50 \mathrm{~nm}$ diameter was demonstrated to bud directly from the PM, similar to virus budding at PM, in a manner that is dependent on ARRDC1 nucleation and ARRDC1-Tsg101 interaction at PM [73]. In cardiomyocytes, ampiphysin-1 (Bin-1) organized membrane microdomains promote actin polymerization and MV release in a CHMP4B-dependent manner [74]. In breast (MDA-MB231) and cervical carcinoma (HeLa) cell lines, activation of RhoA/ROCK signaling and sequential downstream phosphorylation of LIMK1 and cofilin was demonstrated to induce MV budding [75,76]. In monocytes, cholesterol bearing lipid rafts are required to produce MVs [77]. In enterocytes, microvillar tips generate unilamellar vesicles into the lumen in myosin-1a dependent manner [78]. Except for the role of lipid raft-based processes, relevance of the remaining mechanisms in RBCEV biogenesis is 
unknown and none of the major protein regulators of EV biogenesis were identified in either the RBC or RBCEV proteome. Therefore, RBCEV generation represents distinct and cell specific biogenesis mechanisms.

\section{Molecular Composition of RBCEVs}

Proteomic and transcriptomic studies have characterized the protein and nucleic acid components of the RBCEVs. Some of the contents of RBCEVs are shown in Figure 3 and selected studies listing composition, techniques and key findings are listed in the Supplementary Table S1. RBCEVs Information gathered from these studies have been routinely deposited in databases like EVpedia, Exocarta, and Vesiclepedia [79-81] and ExoCarta [82].

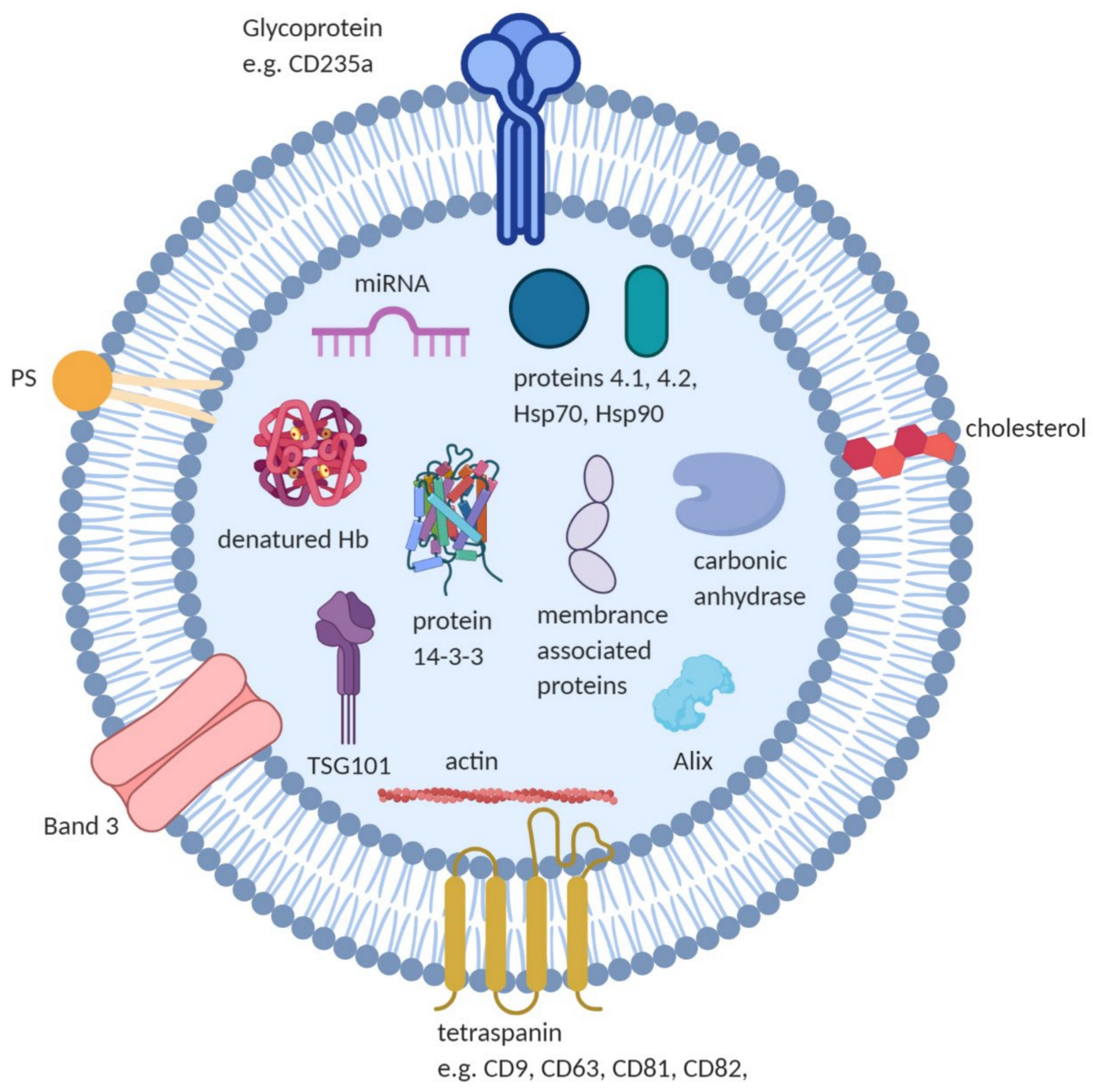

Figure 3. Composition of RBCEVs: RBCEVs are reported to contain cytoskeletal proteins (e.g., actin), irreversibly modified $\mathrm{Hb}$, anion transport proteins (e.g., Band 3), glycoproteins (e.g., CD235a), proteins 4.1, 4.2, and 14-3-3, multivesicular body fusion proteins (e.g., Alix, TSG101), membrane-associated proteins (e.g., stomatin (Band 7.2b) and flotillin) and enzymes like carbonic anhydrase. Negatively charged phospholipids (e.g., phosphatidylserine) and other lipid molecules such as cholesterol, and nucleic acid such as miRNA are reported in RBCEVs. (Figure created with BioRender.com).

The proteomic profiles of total membrane protein extracts and band 3 complexes from stored RBCEVs are described [83]. Comparison of membrane protein extract from RBCs and EVs revealed 32 common proteins, $26 \mathrm{RBC}$-specific and $25 \mathrm{EV}$-specific proteins with an enrichment of acetylcholinesterase in EVs. RBCs and EVs from band 3 complex preparations had 11 common proteins, 5 RBC-specific and $7 \mathrm{MV}$-specific proteins. Com- 
pared to RBCs, band 3 complex derived EVs lacked spectrins but exclusively contained complement $\mathrm{C} 4$ and galectin 7. In the membrane protein preparations, EVs were devoid of membrane-skeleton linking proteins such as ankyrin, proteins 4.1 and 4.2. EVs generated during blood banking are enriched in glycophorin A, lipid raft proteins stomatin and synexin, but depleted in actin compared to intact RBCs $[63,84,85]$. RBC oxidation increases within 3 weeks of storage leading to significantly higher levels of carbonylated proteins in vesicles [86].

MicroRNAs (miRNAs) are a class of small RNAs (20-30nt in length) enriched in RBCs that control gene expression via target mRNA degradation or translation repression [87]. MicroRNAs are involved in regulation of cell differentiation and proliferation, development, apoptosis, hematopoiesis, tumorigenesis, and in different stages of erythropoiesis, including proliferation, differentiation, and maturation [88-92].

Approximately 78 miRNAs are reported within EVs isolated from stored RBCs (3 separate donor units) with a mean size of $64.08 \mathrm{~nm}$. Three miRs-mir-125-b-5p, 4454, and 451awere most abundant and present in all three donor unit isolated exosomes and miR-4454 and miR-451a levels were observed to increase with the duration of refrigerator storage time [93]. RNA sequencing [93] predicted target genes for the top ten most abundant RBC exosomal miRNAs: miR29a-3p, 101-3p, 125b-5p, 22-3p, 30b-5p, 451a, 30c-5p, 4454, $1260 \mathrm{~b}$, and 96-5P [93]. Among those identified, MiR-125b-5p acts as a negative regulator of inflammatory genes through the TRAF6/MAPKs/NF-KB pathway in human osteoarthritic chondrocytes [94] and modulates the inflammatory state of macrophages by targeting B7-H4 [95]. MiR-125b-5p mimics are reported to attenuate liver injury in murine models of acute liver failure [96] and act as anti-multiple myeloma agents in vitro and in vivo [97]. Doss et al. [98] reported 287 known and 72 putative novel miRNAs [98] with miR-451, 144 , and 486, representing abundant genetic residual contents in mature erythrocytes [92]. MiRs-451 present in stored RBCEVs and miR-144 are located within the same gene cluster and are regulated by the erythroid transcription factor GATA1-binding factor 1 during erythropoiesis [92,99].

Furthermore, changes in the RBC microRNA profiles from low and high altitude populations [100] are described. MiRNA-144-5p and miR-30b-5p demonstrate increased expression levels in high altitude dweller's RBCs based on RNA sequencing data and both miRNAs may be involved in erythroid and nitric oxide (NO) related signaling pathways during hypoxia. Some of the miRNAs reported in RBCEVs [93] were either upregulated (miR-30b-5p [101], miR-125b-5p [102], and miR-451a [102,103]) or downregulated (miR101 [104]) during hypoxia. A comprehensive cataloging [105] of cell specific miRNAs derived from human peripheral blood identifies 271 RBC miRNAs, 90 serum miRNAs, and $5 \mathrm{miRNAs}$ compartmentalized within exosomes. Some of these miRNAs are expressed in all the three portions, and some are unique to a particular component of the circulating blood [105].

\section{Biological Roles of RBCEVs}

Under physiological and pathological conditions, RBCEVs loaded with proteins, lipids, and miRNAs might be vital for communication with the endothelium to regulate $\mathrm{NO}$ and $\mathrm{O}_{2}$ homeostasis, redox balance, and immunomodulation. Further, RBCEVs are critical to the dysregulation of hemostasis and demonstrate relevant pro-coagulant effects in several disease states. Roles of small and large RBCEVs during normal communication and pathophysiology are proposed in Figure 4.

\subsection{Nitric Oxide Homeostasis}

$\mathrm{NO}$ is an important signaling molecule that acts as a vasoregulator and modulates the vascular microenvironment. Oxygenated $\mathrm{Hb}$ becomes oxidized by $\mathrm{NO}$ through a deoxygenation reaction that generates metHb and nitrate [106]. Meanwhile, deoxygenated $\mathrm{Hb}$ binds $\mathrm{NO}$ with high affinity at the heme iron $\left(\mathrm{Fe}^{2+}\right)$, altering [107] $\mathrm{NO}$ bioavailability and in turn affecting $\mathrm{O} 2$ homeostasis and vasoregulation. Studies suggest that EVs from 
packed red blood cell units scavenge $\mathrm{NO}$ at a slower rate than extracellular $\mathrm{Hb}$, but at a faster than RBC-encapsulated $\mathrm{Hb}[108,109]$. RBCEVs impact on NO bioavailability depends on several factors including the abundance of particles entering the microcirculation and their proximity to the endothelium. In vitro and in vivo studies have shown that RBCEVs by enhancing ROS production disturb NO homeostasis leading to endothelial dysfunction [110-112]. RBCEVs from JAK2 ${ }^{\mathrm{V} 617 \mathrm{~F}}$ myeloproliferative neoplasms increase endothelial oxidative stress leading to NO pathway inhibition [111].

\subsection{Redox Balance}

RBCs maintain a balance between the pro-oxidant and antioxidant status within the circulation. RBCs are well equipped with antioxidant enzymes such as thioredoxin reductase/peroxiredoxin system, superoxide dismutase, catalase, glutathione peroxidase, glutathione reductase, and reducing equivalents as well as non-enzymatic antioxidants: glutathione, ascorbic acid, a-tocopherol, and thioredoxin [113]. Further, RBCs function as critical compartments for the reduction of oxidized small molecule antioxidants such as dehydro-ascorbic acid. However, oxidative processes within the RBC that typically occur ex vivo (under storage conditions) or in vivo (following transfusion or during disease) leads to RBCEVs that can be involved in causing respiratory burst as well as neutrophil activation characterized by rapid release of the reactive oxygen species (ROS) [114,115]. Co-incubation of RBCEVs with neutrophils results in the generation of reactive oxygen species as well as transfer of vesicular components to cells. This effect of RBCEVs on neutrophils is suggested to be caused by the accumulation of lysophospholipid in vesicles that contribute toward the pathogenesis of transfusion-related acute lung injury [114].

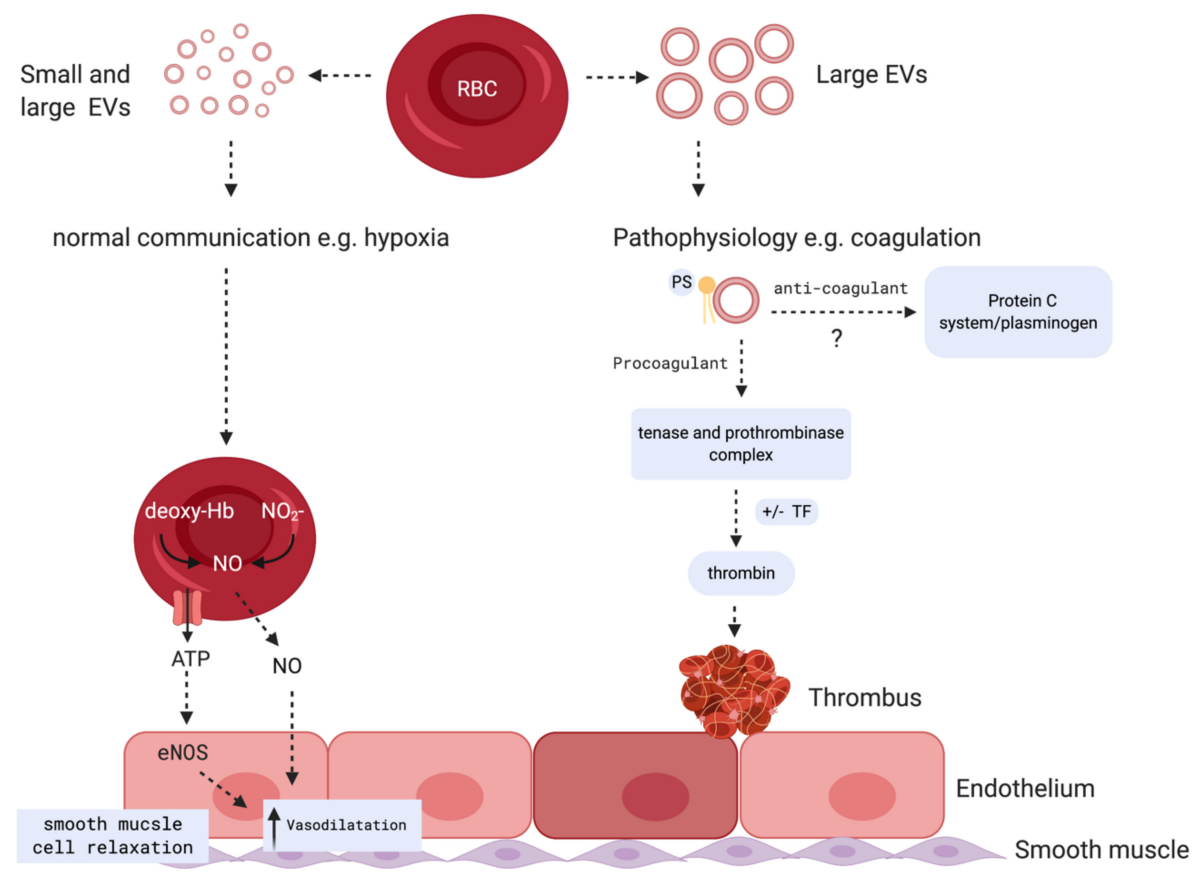

Figure 4. Potential biological role of RBCEVs: During hypoxia, small and large RBC vesicles carry factors that are responsible for NO production mediated by eNOS, resulting in an increase in vasodilation and smooth muscle cell relaxation (left panel). Large RBC vesicles are reported to play both pro and potential anti-coagulant roles (right panel): MVs mediate procoagulant activities by facilitating assembly of tenase and prothrombinase complexes on phosphatidylserine and promoting thrombin generation. Potential ability of MVs to mediate anticoagulant reactions through their interactions with protein $\mathrm{S}$ and activation of anticoagulant protein $\mathrm{C}$ system and plasminogen on their surface was reported. This process, in some circumstances, may create an anti-inflammatory and anti-coagulant response based on EV release from certain cells including neutrophils and platelets [116]. (Figure created with BioRender.com). 


\subsection{Immunomodulation}

The immunomodulatory effects of RBCEVs were reviewed in greater detail elsewhere [117-119]. In vitro studies suggest that mixing of RBCEVs with peripheral blood mononuclear cells (PBMCs) causes secretion of proinflammatory chemokines and cytokines and increases the survival of unstimulated PBMCs [115]. This induction of proinflammatory cytokines appears to be mediated by the interactions between the exosome fraction of either platelet, endothelial, or RBC origin EVs and monocytes [115]. Further RBCEVs amplified the replication of mitogen-induced CD4+ and CD8+ T-lymphocytes in an antigenpresenting cell dependent manner. Another study by Fisher et al. also demonstrated the induction of proinflammatory cytokines from PBMCs by RBCEVs. This study also demonstrated the increased interaction of platelets with neutrophils and monocytes upon incubation with RBCEVs. Additionally, RBCEVs from stored units bind to monocytes to activate endothelial cells by a $\beta$-integrin mediated process [120]. The interactions between RBCEVs and monocytes could impact post-transfusion complications by triggering proinflammatory cytokines secretion, and through neutrophil and platelets interactions [115,121].

After macrophage exposure to zymosan A and lipopolysaccharide, phagocytosed RBCEVs demonstrate immunosuppressive effects that lead to inhibition of tumor necrosis factor- $\alpha$ and release of interleukin 8 [122]. The immune suppressive effects of syngeneic RBC transfusion in murine models of delayed-type hypersensitivity are described [123]. Administration of syngeneic RBCs generate CD9 and CD81 positive EVs that are able to suppress delayed-type hypersensitivity mediated through miRNA-150 [123]. Further, a decrease in T-cell activation and an increase in apoptosis were observed when delayed-type hypersensitivity effector cells were treated with EVs from syngeneic RBCs in these models. EVs from Plasmodium infected RBCs exert their immunomodulatory role on human primary macrophages and neutrophils [116].

\subsection{Critical Role for RBCEVs in Coagulopathy}

The procoagulant activity of RBCEVs is well documented and represents the most well studied areas of RBCEV driven disease sequelae. The shortening of plasma clotting time by RBC lysates dates back to 1961 [124]. In 2006, experimental observations suggest that the addition of RBC lysate to intact RBC or platelets amplifies thrombin generation (TG) as evidenced by increased endogenous thrombin potential (ETP), maximal thrombin concentration and decreased time to reach peak TG [125]. This thrombogenic potential of RBC lysate was not observed when lysate was filtered through $0.22 \mu \mathrm{m}$ filter. The data suggest an important role for RBC membranes and potentially RBCEVs rather than soluble proteins in the process of thrombogenesis. Phosphatidylserine (PS) exposed on the outer membrane is known to mediate the procoagulant activity of RBCEVs. The negatively charged PS interacts with gamma-carboxyglutamic acid (Gla) rich domains of coagulation factors in the presence of calcium acting as a docking site for the formation of tenase and prothrombinase complexes $[126,127]$. RBCEVs drive TG through the intrinsic pathway of coagulation because deficiency of factor XII, but not factor VII, is an inhibitor of TG. This observation also suggests a tissue factor independent initiation of coagulation [127]. Conversely, the ability of RBCEVs to interact with protein $S$ and support activated protein $C$ mediated anticoagulant reaction [128] and mediation of fibrinolytic activity, primarily from the presence of plasminogen on their surface [129] was also demonstrated. The significance of these anticoagulant interactions in disease states is not clear and to our knowledge not studied.

\subsubsection{Pro-Coagulant RBCEVs Generated under Blood Banking Conditions}

RBCs stored ex-vivo under blood banking conditions intended for transfusion undergo several changes including loss of membrane and cell volume through shedding of RBCEVs [84,130]. A significant increase in the concentration of RBCEVs following storage at $4^{\circ} \mathrm{C}$ was reported by multiple studies $[84,130,131]$. Further, RBCEVs accumulated during refrigerated storage were demonstrated to express PS on their surface $[130,132]$. 
The procoagulant activity of RBCEVs secreted from stored RBCs is suggested by results that demonstrate significantly decreased clotting time, enhanced procoagulant activity [130], and increased TG [132,133]. Ex vivo storage of RBCs for transfusion may lead to the accumulation of cell-free $\mathrm{Hb}$ containing RBCEVs [108,109]. Hb containing RBCEVs act as scavengers of $\mathrm{NO}$ and lead to systemic vasoconstriction in rodent models of transfusion $[108,109]$. The ability of RBCEVs to scavenge NO is proposed to be dependent on their ability to reach the RBC-free layer, parallel to endothelial cells [109]. Under in vitro conditions, $\mathrm{Hb}$ containing RBCEVs were shown to transfer heme to human umbilical cord vascular endothelial cells and induced oxidative stress and apoptosis [134]. Further, loss of NO homeostasis activates platelets and promotes a pro thrombotic state $[135,136]$. It is suggested that the $\mathrm{NO}$ scavenging capability of $\mathrm{Hb}$ containing RBCEVs may contribute toward this process [137]. In murine models of SCA, injection of ex vivo generated $\mathrm{Hb}$ containing RBCEVs led to rapid vaso-occlusion within the renal glomerular circulation, while administration of the heme scavenger, hemopexin prevented renal vascular microthrombi [134]. Taken together, $\mathrm{Hb}$ containing RBCEVs can alter $\mathrm{NO}$ bioavailability and promote heme mediated endothelial dysfunction. Abnormal RBC metabolism is the primary driver of RBCEV accumulation, hemolysis, morphological changes, and reduced deformability that occurs during $\mathrm{RBC}$ refrigerator storage and each can individually or collectively contribute toward complications associated with transfusion [138].

\subsubsection{Pro-Coagulant RBCEVs Generated in Health and Disease}

In healthy individuals, circulating EVs contribute to low grade TG. Depletion of microparticles from platelet-free plasma of healthy individuals results in delayed lag time and time to peak TG, as well as increased sensitivity to fibrinolysis [139-141]. However, differences in analysis of circulating EVs can generate differing results. For example, studies suggest no differences in the peak height value of TG or endogenous thrombin potential [141] of isolated circulation EVs, while other studies suggest a decrease in both parameters [139]. These discrepancies seem to be a result of differences in filtration methods employed (use of $0.1 \mu \mathrm{m}$ vs. $0.2 \mu \mathrm{m}$ filters) in generating EV-depleted plasma. Relative contribution of RBCEVs to TG in healthy individuals is likely lower than circulating EVs generated by platelets, endothelial cells, and leukocytes [140].

Elevated levels of circulating procoagulant EVs and their contribution towards hypercoagulability and increased thrombosis of hemolytic disorders including SCA, beta thalassemia (BT), and paroxysmal nocturnal hemoglobinuria $(\mathrm{PNH})$ are reported $[142,143]$. Of these hemolytic conditions, contribution of RBCEVs to the pathophysiology of SCA is particularly well studied. Presence of RBCEVs in SCA patient blood was first described in 1982 [144]. Since then, multiple studies identified elevated levels of RBCEVs in SCA patient plasma compared to healthy controls and suggested their role in the hypercoagulability of SCA [145-151]. Some studies identified further increases in the levels of RBCEVs in SCA patients during crisis compared to SCA patients at steady state [149,151-153]. However, complicating interpretation of data some studies have identified no significant differences in EV generation in SCA [145,146], while other experimental findings suggest increased levels of platelet-derived microparticles compared to RBCEVs in SCA [146-148,150,151,153-155]. Research efforts have attempted to assess RBCEVs in SCA patients to categorize non-severe and severe vaso-occlusive crises based on their circulating levels [150]. Further, comparison of circulating EVs between SCA and $\mathrm{Hb}$ SC ( $\mathrm{HbSC}$ ) genotype patients identified significantly higher levels of total microparticles including both RBC- and platelet-derived EVs in SC compared to HbSC patients [155].

In a study by Shet et al., addition of SCA-patient-derived circulatory EVs to plasma increased clotting time compared to control EVs from healthy control subjects [145]. Addition of an anti-tissue factor antibody partially inhibited the procoagulant activity in this study suggesting the presence of both tissue factor dependent and independent coagulation activity [145]. Similarly, in a study by van Beers et al., total TG correlated with the number of circulatory EVs and the thrombin activity was significantly blocked by anti-human 
factor XI, unaffected by anti-human factor VII, and modestly increased by anti-tissue factor pathway inhibitor antibody, upon co-incubation [146]. Importantly, the extent of factor XI inhibition correlated with the number of RBCEVs, suggesting the primary contribution of RBCEVs to the observed thrombogenicity. Additionally, the number of RBCEVs correlated with markers of hemolysis ( $\mathrm{Hb}$ and lactate dehydrogenase), platelet/endothelial cell activation (vWF antigen), and fibrinolysis (prothrombin fragment F1+2 and D-dimers) analyzed in this study [146]. Gerotziafas et al. identified acceleration of the propagation phase of TG in SCA patient plasma and determined that RBCEVs expressing PS are the major contributory factors. Further, the authors demonstrate that hydroxyurea treatment reduced the number of procoagulant RBCEVs and TG in SCA patients [147]. In this context, it must be added that variable effects of hydroxyurea treatment on RBCEV production were demonstrated [[147,154]. In a study assessing the effects of red cell exchange on circulatory EVs accumulation, a significant decrease in RBC-derived, but not platelet-derived EVs was observed [148]. Overall, RBCEVs are reported to be elevated in SCA and potentially contribute to SCA pathophysiology and coagulopathy. Nonetheless, differences in SCA severity and progression of the disease in patients as well as experimental study design were identified as potential reasons for discrepancies in data across studies assessing RBCEVs role in SCA [156].

BT intermedia and major forms are both associated with a hypercoagulable state and increased incidence of thrombosis [157,158]. Elevated levels of circulating EVs including RBCEVs in BT are reported in multiple studies [159-165]. In splenectomized BT patients, a significant increase in the number of circulating RBCEVs is observed compared to nonsplenectomized patients $[159,160,164,165]$. Despite elevated levels, contribution of RBCEVs to hypercoagulability of BT is not clear. In a study by Chaichompoo et al., EVs derived from platelets are suggested to be the primary pro-coagulant EVs in BT since the levels of microparticles with prothrombinase activity correlated with platelet numbers [162]. Tripodi et al. identified hypercoagulability in patients using whole blood thromboelastography, but not by TG in platelet-poor plasma, and concluded platelet and/or blood cell components as the primary determinants of thrombotic risk in BT [166].

$\mathrm{PNH}$ is a hematological disorder that is clinically associated with complement-driven intravascular hemolysis, thrombosis, and anemia $[167,168]$. Thromboembolism is identified as the most common cause of mortality in patients suffering from attacks of PNH and accounts for up to $67 \%$ of deaths in this rare disease [167,168]. During bouts of $\mathrm{PNH}$, EVs are released from complement activated RBCs and demonstrate increased TG when compared to EVs released from normal RBCs. This may indicate a thrombogenic RBCEV subtype in certain patients that contributes toward hypercoagulability and thrombosis during bouts of PNH [169]. However, lower levels of RBC-derived procoagulant EVs are found when compared to platelet EV concentrations in PNH patient plasmas [170,171]. Overall, these findings suggest a lesser contribution of RBCEVs to the prothrombotic state observed in most PNH patients $[167,168]$.

The contributory role of reticulocyte-derived EVs to coagulopathy is not clear from the existing literature. Generation of exosomes from reticulocytes is well established, but their ability to produce MVs requires a more extensive understanding. The membranes of reticulocyte-derived exosomes contain 20\% exposed PS [172] and Mankelow et al. [173] reported elevated levels of reticulocytes expressing PS-exposed autophagic vesicles in SCD patients and proposed that failure to remove these vesicles by spleen could contribute to a hypercoagulable state and increased thrombotic events. Considering the primary contribution of PS to coagulation and immunomodulatory properties of RBCEVs [122,126,127], studies are needed to explore the contribution of reticulocyte-derived EVs to the pathophysiology of disease conditions, specifically hemolytic disorders where the numbers of reticulocytes in peripheral blood are elevated.

In summary, RBCEVs are elevated upon storage and in several genetic non-malignant hematologic disease states. Together with alterations in cellular components, pro-coagulant 
factors, fibrinolytic factors, and platelet-derived EVs, our understanding of RBCEVs role as contributors toward hypercoagulability and thrombogenicity continues to evolve.

\section{Therapeutic Opportunities for RBCEVs}

Beginning in 2010, EV-based therapeutics research has focused on several areas of disease including cancer [174,175], cardiovascular disease [176,177], central nervous system (CNS) disorders [178], as well as pulmonary [179], hepatic [180], and renal disease [181]. Delivery of miRNA or siRNA payload using EVs has focused on anti-cancer treatments in rodent models of glioma [182], carcinoma [183], and pancreatic cancer [184,185]. Data from these preliminary studies suggest that EVs effectively enter tissue parenchymal and tumor cells delivering their RNA cargo. When compared with liposomes, preliminary studies further suggest that EVs minimize immune response and may offer a novel delivery system $[174,175,182]$.

Human RBCs can be stimulated to produce EVs for RNA therapies because they lack both nuclear and mitochondrial DNA [186]. A RBCEV platform was used to deliver RNAbased therapeutics to treat solid and liquid tumors in breast cancer and acute myeloid leukemia (AML) cell lines, respectively [187]. In these proof-of-concept studies RNAloaded RBCEVs were absorbed by both breast cancer and AML cells with high efficiency. In AML, MOLM13 engrafted mice RBCEV-miR-125b antisense oligonucleotides suppressed miR-125b expression levels, cancer cell proliferation, and infiltration. Efficient engraftment of RBCEV-antisense oligonucleotides in human metastatic breast cancer MCF10CA1a cells were observed using in vivo fluorescent imaging. Lipophilic drugs such as camptothecin packaged within RBCEVs are observed to be taken up by lung carcinoma cells and show an improvement in targeted delivery in vivo when compared with synthetic lipid-based nanocarriers [188]. RBCEVs are effective packaging and delivery systems for iron oxide to target human bone marrow mesenchymal stem cells for magnetic resonance imaging studies [189]. However, the limitations associated with large-scale production and purification of natural exosomes were overcome by the production of exosome mimetics (EMs) from RBCs. Gangadaran et al. generated EMs from RBCs by a one-step extrusion method that had 130-fold greater yield compared to natural NVs generated from RBCs and displayed enhanced in vivo biodistribution [190].

Although small molecules or biologics remain the most common therapeutics, several limitations may apply including poor bioavailability, high dose requirements, nonspecific targeting, drug resistance, and low therapeutic indices. These limitations have advanced with the advent of nanoparticle (NP)-based drug delivery formulations that display enhanced permeability and retention (EPR) effect, improved stability, favorable toxicological profiles, optimized biocompatibility, longer shelf lives, as well as increased therapeutic release efficiency. However, NPs often lack selective features for tissue targeting (e.g., selective tumor targeting/tumor cell binding) and extended blood circulation times, thus limiting their clinical applications to date [191]. This is in part due to immune clearance of NPs by the reticuloendothelial and mono-nuclear phagocytic systems. To overcome this issue, surface functionalization of NPs with polyethylene glycol (PEG) were incorporated into formulations to improve pharmacokinetic exposures by reducing rates of immune clearance [192]. However, appearance of anti-PEG immune response upon repeated administrations resulted in lowered drug efficacy, shifting the focus towards biomimetic particles that mimic self and therefore do not trigger an immune response [193]. Furthermore, biomimetic particles comprise several biological features of biocompatibility, biodegradability, selective tumor targeting, and extended circulatory half-life. The principle of generating biomimetic NPs involve "coating or camouflaging" NPs with membranes derived from bacteria, tumor cells, lymphocytes, platelets, leucocytes, and RBCs. Among these, RBCs represent an excellent source of membranes due to their abundance ( 5 billion $\mathrm{RBC} / \mathrm{mL}$ of blood), biocompatibility, extended circulation (120-day life-span), and lack of internal organelles and nucleus easing the membrane extraction procedures [194-199]. 
Several integral membrane proteins in RBC membranes serve as self-markers that prevent immune clearance and allow extended circulation. For instance, CD47 serves as a "don't eat me" signal which interacts and signals via signal regulatory protein alpha (SIRP $\alpha$ ) on macrophage surface and thus inhibits macrophage engulfment of RBCs [200,201]. Similarly, membrane proteins, C8 binding protein (C8bp) [202], homologous restriction protein (HRP) [203], decay accelerating factor (DAF) [204], membrane cofactor protein (MCP), complement receptor 1 (CR1), and CD59 prevent attack by complement complexes [205]. Thus, surface proteins on RBC membranes present themselves as "self" facilitating extended circulation. Consistent with this, RBC membrane-coated NPs exhibited an elimination half-life of $39.6 \mathrm{~h}$, compared to PEGylated NPs (15.8 h) [206].

Generation of RBC membrane-coated nanoparticles (NPs) involves the production of RBC membrane-derived vesicles (RVs) followed by vesicle-NP fusion [207]. RVs are generated in two steps. First, hypotonic treatment of pure RBCs separated from blood serum and buffy coat followed by a centrifugation step results in the removal of intracellular components and generates RBC ghost membranes. This step is followed by sonication and sequential extrusion through various pore size polycarbonate membranes to achieve target vesicle size [207-209]. Second, various methods of vesicle-nanoparticle fusion exist including co-extrusion, microfluidic electroporation and cell membrane templated polymerization. Both mechanical extrusion and microfluidic electroporation methods incorporate principles of interfacial interactions where negative charged sialyl residues on surface polysaccharides confer a charge asymmetry, which facilitates interactions between RVs and NPs [210]. Negatively charged sialyl moieties on the outer membrane side undergo a strong electrostatic repulsion with negatively charged NPs to fuse with the intracellular membrane side in a right-side-out-membrane orientation [211]. In contrast, negatively charged sialyl moieties likely display strong affinity towards positively charged NPs resulting in the collapse of lipid bilayer and hindering the local arrangement necessary for lipid covering [211].

In the co-extrusion method, NPs are fused with RVs via mechanical extrusion. Depending on NP size, NP and RV mixture is extruded through porous membranes of different sizes prior to water bath sonication. The mechanical force during extrusion allows for NPs passage through the lipid bilayer, causing vesicle-particle fusion [210]. After repeated extrusions, the excess RVs are removed by centrifugation, and RV-NP precipitates representing the final product are collected and dispersed for future use [209]. An example of the microfluidic electroporation process involves iron oxide $\left(\mathrm{Fe}_{3} \mathrm{O}_{4}\right)$ magnetic nanoparticles (MNPs) and RVs combined on a microfluidic chip. The mixture is flown through an electroporation zone [211]. The electrical pulses can break down the dielectric layer on the cell membranes to create multiple transient pores and allow integration of MNPs into RVs [212]. Upon integration, RV-MNPs are collected from chips and used for in vivo performance tests. Under conditions where interfacial interactions between RV membranes and NPs are hindered due to the use of non-compliant NP core materials, cell membrane-template polymerization method are incorporated to synthesize polymer cores via in situ polymerization to form cell membrane-coated nanogels [213]. Several polymeric core NPs including poly(caprolactone) PCL NPs [214], poly pyrrole (PPy) NPs [215,216], poly (lactide acid) (PLA) NPs [217,218], poly (D, L-lactide-co-glycolide) (PLGA) NPs [219-222] and other types, including $\mathrm{Fe}_{3} \mathrm{O}_{4}$ MNPs [223-225], MNP clusters [226-228], mesoporous silica NPs [229,230], up conversion NPs (UCNPs) [231-235], gold nanoparticles (AuNPs) $[230,236,237]$, and gelatin NPs [238,239] have been successfully coated with RBC membranes and evaluated for their potential use in several biomedical applications including chemotherapy, phototherapy, and diagnostic imaging [240]. For an in-depth review of preparation and therapeutic uses of RVs, readers are directed to Castro E. et al. [240]. 


\section{Conclusions}

EVs comprising exosomes and MVs originate from endosomes and PM, respectively. Although EVs in general are best known for their functions in intercellular communication, $\mathrm{EV}$ biogenesis and release have integral roles in RBC maturation, ageing and disease. MV release during RBC maturation and ageing involves disposal of unwanted membrane proteins and damaged $\mathrm{Hb}$ coupled with membrane remodeling. Furthermore, both in vitro storage and hematological diseases are known to generate MVs that contribute toward immunomodulation, inflammation, and coagulation.

Increased circulating EVs may contribute toward hypercoagulability and thrombosis after refrigerator storage and are suggested to interfere with nitric oxide signaling, which leads to endothelial dysfunction as well as perfusion and oxygenation deficiency. Hemolytic disorders including SCA, BT, and PNH are a primary focus of this short review and these disease states continue to be the most studied as they relate to the biogenesis and pathophysiology of RBCEVs. However, there remain critical questions that apply to the true impact of RBCEVs generated under storage conditions or during disease. While there is some indication as to the role of RBCEVs under certain circumstances, the literature remains largely inconsistent in its results and conclusions. Nonetheless, therapeutics based on RBCEVs are being studied with some degree of sophistication. This is largely inconsistent with the proof-of-concept required for therapeutics development and completely void of the potential for toxicological risk assessment.

Based on our assessments of the literature to date, it remains clear that a greater understanding of RBCEV generation, physiology, and pathophysiology should be a goal of future scientific endeavors. More specifically, studies suggest that RBCEVs play relevant communicative roles that alter tissue adaptation to disease and environment. This work represents a logical and intriguing role for RBCs given their abundance and proximity to tissues and cells. Nonetheless, future studies require more in-depth assessments of how communication between RBCs and tissues occurs. These studies should be directed at the origin, packaging, release triggers, and target tissue phenotype altering effects specific to RBC miRNA transfer and the true relevance of such processes.

Supplementary Materials: The following are available online at https:/ /www.mdpi.com/1422-006 7/22/1/153/s1, Table S1: Selective studies evaluating the implications of RBC extracellular vesicles: Due to overlapping data selective studies on RBCEVs are provided in chronological order with emphasis on RBC source, composition, size and key findings.

Funding: This research received no external funding.

Conflicts of Interest: The authors declare no conflict of interest.

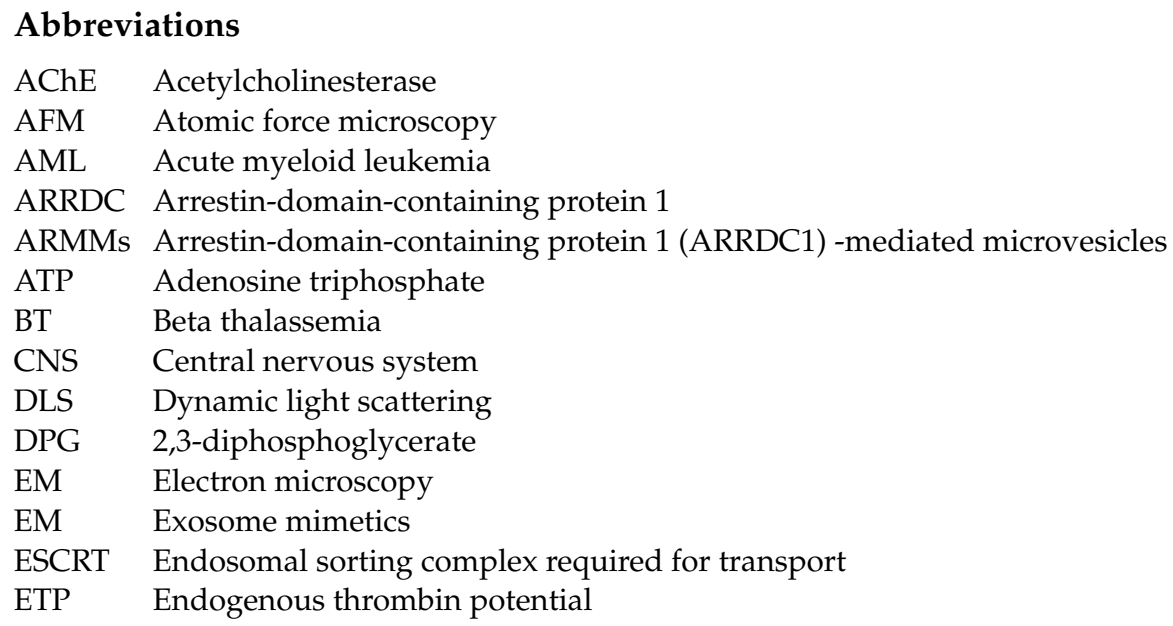




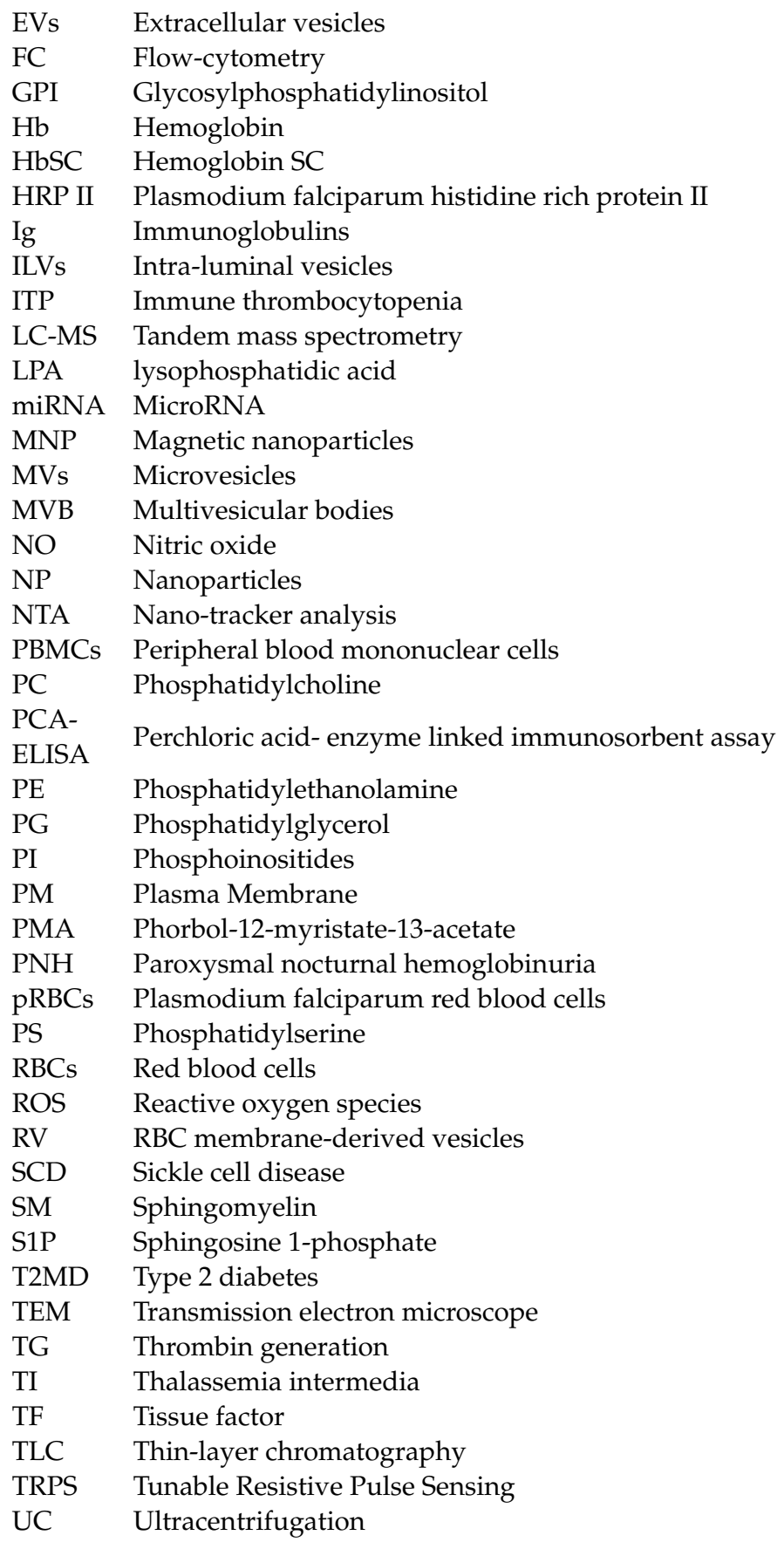

\section{References}

1. van Niel, G.; D'Angelo, G.; Raposo, G. Shedding light on the cell biology of extracellular vesicles. Nat. Rev. Mol. Cell Biol. 2018, 19, 213-228. [CrossRef]

2. Horder, E. Blood dust or blood granules: A new constituent of the blood? Lancet 1899, 154, 1015. [CrossRef]

3. Nguyen, D.B.; Ly, T.B.T.; Bernhardt, I. Microvesicles Released from Human Red Blood Cells: Properties and Potential Applications; IntechOpen: Rijeka, Croatia, 2017; Volume 10.

4. Johnstone, R.M.; Adam, M.; Hammond, J.R.; Orr, L.; Turbide, C. Vesicle formation during reticulocyte maturation. Association of plasma membrane activities with released vesicles (exosomes). J. Biol. Chem. 1987, 262, 9412-9420. [PubMed]

5. Yáñez-Mó, M.; Siljander, P.R.M.; Andreu, Z.; Zavec, A.B.; Borràs, F.E.; Buzas, E.I.; Buzas, K.; Casal, E.; Cappello, F.; Carvalho, J.; et al. Biological properties of extracellular vesicles and their physiological functions. J. Extracell Vesicles 2015, 4, 27066. [CrossRef]

6. Szatanek, R.; Baj-Krzyworzeka, M.; Zimoch, J.; Lekka, M.; Siedlar, M.; Baran, J. The Methods of Choice for Extracellular Vesicles (EVs) Characterization. Int. J. Mol. Sci. 2017, 18, 1153. [CrossRef] [PubMed] 
7. Robbins, P.D.; Morelli, A.E. Regulation of immune responses by extracellular vesicles. Nat. Rev. Immunol. 2014, 14, 195208. [CrossRef]

8. Harding, C.; Heuser, J.; Stahl, P. Receptor-mediated endocytosis of transferrin and recycling of the transferrin receptor in rat reticulocytes. J. Cell Biol. 1983, 97, 329-339. [CrossRef]

9. Pan, B.T.; Johnstone, R.M. Fate of the transferrin receptor during maturation of sheep reticulocytes in vitro: Selective externalization of the receptor. Cell 1983, 33, 967-978. [CrossRef]

10. Théry, C.; Witwer, K.W.; Aikawa, E.; Alcaraz, M.J.; Anderson, J.D.; Andriantsitohaina, R.; Antoniou, A.; Arab, T.; Archer, F.; Atkin-Smith, G.K.; et al. Minimal information for studies of extracellular vesicles 2018 (MISEV2018): A position statement of the International Society for Extracellular Vesicles and update of the MISEV2014 guidelines. J. Extracell. Vesicles 2018, 7, 1535750. [CrossRef]

11. Raposo, G.; Stoorvogel, W. Extracellular vesicles: Exosomes, microvesicles, and friends. J. Cell Biol. 2013, 200, 373-383. [CrossRef]

12. Buschow, S.I.; Nolte-'t Hoen, E.N.M.; van Niel, G.; Pols, M.S.; ten Broeke, T.; Lauwen, M.; Ossendorp, F.; Melief, C.J.M.; Raposo, G.; Wubbolts, R.; et al. MHC II in dendritic cells is targeted to lysosomes or T cell-induced exosomes via distinct multivesicular body pathways. Traffic 2009, 10, 1528-1542. [CrossRef] [PubMed]

13. Theos, A.C.; Truschel, S.T.; Tenza, D.; Hurbain, I.; Harper, D.C.; Berson, J.F.; Thomas, P.C.; Raposo, G.; Marks, M.S. A lumenal domain-dependent pathway for sorting to intralumenal vesicles of multivesicular endosomes involved in organelle morphogenesis. Dev. Cell 2006, 10, 343-354. [CrossRef] [PubMed]

14. Villarroya-Beltri, C.; Baixauli, F.; Mittelbrunn, M.; Fernández-Delgado, I.; Torralba, D.; Moreno-Gonzalo, O.; Baldanta, S.; Enrich, C.; Guerra, S.; Sánchez-Madrid, F. ISGylation controls exosome secretion by promoting lysosomal degradation of MVB proteins. Nat. Commun. 2016, 7, 13588. [CrossRef] [PubMed]

15. Edgar, J.R.; Manna, P.T.; Nishimura, S.; Banting, G.; Robinson, M.S. Tetherin is an exosomal tether. Elife 2016, 5, e17180. [CrossRef] [PubMed]

16. Guix, F.X.; Sannerud, R.; Berditchevski, F.; Arranz, A.M.; Horré, K.; Snellinx, A.; Thathiah, A.; Saido, T.; Saito, T.; Rajesh, S.; et al. Tetraspanin 6: A pivotal protein of the multiple vesicular body determining exosome release and lysosomal degradation of amyloid precursor protein fragments. Mol. Neurodegener. 2017, 12, 25. [CrossRef] [PubMed]

17. Tamai, K.; Tanaka, N.; Nakano, T.; Kakazu, E.; Kondo, Y.; Inoue, J.; Shiina, M.; Fukushima, K.; Hoshino, T.; Sano, K.; et al. Exosome secretion of dendritic cells is regulated by Hrs, an ESCRT-0 protein. Biochem. Biophys. Res. Commun. 2010, 399, 384-390. [CrossRef]

18. Blanc, L.; Liu, J.; Vidal, M.; Chasis, J.A.; An, X.; Mohandas, N. The water channel aquaporin-1 partitions into exosomes during reticulocyte maturation: Implication for the regulation of cell volume. Blood 2009, 114, 3928-3934. [CrossRef]

19. Wolf, P. The nature and significance of platelet products in human plasma. Br. J. Haematol. 1967, 13, 269-288. [CrossRef]

20. Hristov, M.; Erl, W.; Linder, S.; Weber, P.C. Apoptotic bodies from endothelial cells enhance the number and initiate the differentiation of human endothelial progenitor cells in vitro. Blood 2004, 104, 2761-2766. [CrossRef]

21. Hurley, J.H.; Hanson, P.I. Membrane budding and scission by the ESCRT machinery: It's all in the neck. Nat. Rev. Mol. Cell Biol. 2010, 11, 556-566. [CrossRef]

22. Penalva, M. Faculty Opinions recommendation of Escrt-III: An endosome-associated heterooligomeric protein complex required for mvb sorting. Fac. Opin. Post Publ. Peer Rev. Biomed. Lit. 2002. [CrossRef]

23. Babst, M.; Katzmann, D.J.; Snyder, W.B.; Wendland, B.; Emr, S.D. Endosome-associated complex, ESCRT-II, recruits transport machinery for protein sorting at the multivesicular body. Dev. Cell 2002, 3, 283-289. [CrossRef]

24. Bilodeau, P.S.; Winistorfer, S.C.; Kearney, W.R.; Robertson, A.D.; Piper, R.C. Vps27-Hse1 and ESCRT-I complexes cooperate to increase efficiency of sorting ubiquitinated proteins at the endosome. J. Cell Biol. 2003, 163, 237-243. [CrossRef] [PubMed]

25. Katzmann, D.J.; Babst, M.; Emr, S.D. Ubiquitin-dependent sorting into the multivesicular body pathway requires the function of a conserved endosomal protein sorting complex, ESCRT-I. Cell 2001, 106, 145-155. [CrossRef]

26. Katzmann, D.J.; Stefan, C.J.; Babst, M.; Emr, S.D. Vps27 recruits ESCRT machinery to endosomes during MVB sorting. J. Cell Biol. 2003, 162, 413-423. [CrossRef] [PubMed]

27. Baietti, M.F.; Zhang, Z.; Mortier, E.; Melchior, A.; Degeest, G.; Geeraerts, A.; Ivarsson, Y.; Depoortere, F.; Coomans, C.; Vermeiren, E.; et al. Syndecan-syntenin-ALIX regulates the biogenesis of exosomes. Nat. Cell Biol. 2012, 14, 677-685. [CrossRef] [PubMed]

28. Stuffers, S.; Sem Wegner, C.; Stenmark, H.; Brech, A. Multivesicular endosome biogenesis in the absence of ESCRTs. Traffic 2009, 10, 925-937. [CrossRef]

29. van Niel, G.; Charrin, S.; Simoes, S.; Romao, M.; Rochin, L.; Saftig, P.; Marks, M.S.; Rubinstein, E.; Raposo, G. The tetraspanin CD63 regulates ESCRT-independent and -dependent endosomal sorting during melanogenesis. Dev. Cell 2011, 21, 708-721. [CrossRef]

30. Trajkovic, K.; Hsu, C.; Chiantia, S.; Rajendran, L.; Wenzel, D.; Wieland, F.; Schwille, P.; Brügger, B.; Simons, M. Ceramide triggers budding of exosome vesicles into multivesicular endosomes. Science 2008, 319, 1244-1247. [CrossRef]

31. Perez-Hernandez, D.; Gutiérrez-Vázquez, C.; Jorge, I.; López-Martín, S.; Ursa, A.; Sánchez-Madrid, F.; Vázquez, J.; Yáñez-Mó, M. The intracellular interactome of tetraspanin-enriched microdomains reveals their function as sorting machineries toward exosomes. J. Biol. Chem. 2013, 288, 11649-11661. [CrossRef]

32. Kajimoto, T.; Okada, T.; Miya, S.; Zhang, L.; Nakamura, S.-I. Ongoing activation of sphingosine 1-phosphate receptors mediates maturation of exosomal multivesicular endosomes. Nat. Commun. 2013, 4, 2712. [CrossRef] [PubMed] 
33. van Niel, G.; Bergam, P.; Di Cicco, A.; Hurbain, I.; Lo Cicero, A.; Dingli, F.; Palmulli, R.; Fort, C.; Potier, M.C.; Schurgers, L.J.; et al. Apolipoprotein E Regulates Amyloid Formation within Endosomes of Pigment Cells. Cell Rep. 2015, 13, 43-51. [CrossRef] [PubMed]

34. Gauthier, S.A.; Pérez-González, R.; Sharma, A.; Huang, F.-K.; Alldred, M.J.; Pawlik, M.; Kaur, G.; Ginsberg, S.D.; Neubert, T.A.; Levy, E. Enhanced exosome secretion in Down syndrome brain-A protective mechanism to alleviate neuronal endosomal abnormalities. Acta Neuropathol. Commun. 2017, 5, 65. [CrossRef] [PubMed]

35. Odintsova, E.; van Niel, G.; Conjeaud, H.; Raposo, G.; Iwamoto, R.; Mekada, E.; Berditchevski, F. Metastasis suppressor tetraspanin CD82/KAI1 regulates ubiquitylation of epidermal growth factor receptor. J. Biol. Chem. 2013, 288, 26323-26334. [CrossRef]

36. Vidal, M.; Mangeat, P.; Hoekstra, D. Aggregation reroutes molecules from a recycling to a vesicle-mediated secretion pathway during reticulocyte maturation. J. Cell Sci. 1997, 110 Pt 16, 1867-1877.

37. Blanc, L.; De Gassart, A.; Géminard, C.; Bette-Bobillo, P.; Vidal, M. Exosome release by reticulocytes-An integral part of the red blood cell differentiation system. Blood Cells Mol. Dis. 2005, 35, 21-26. [CrossRef]

38. Ney, P.A. Normal and disordered reticulocyte maturation. Curr. Opin. Hematol. 2011, 18, 152-157. [CrossRef]

39. Díaz-Varela, M.; de Menezes-Neto, A.; Perez-Zsolt, D.; Gámez-Valero, A.; Seguí-Barber, J.; Izquierdo-Useros, N.; Martinez-Picado, J.; Fernández-Becerra, C.; Del Portillo, H.A. Proteomics study of human cord blood reticulocyte-derived exosomes. Sci. Rep. 2018, 8, 14046. [CrossRef]

40. Carayon, K.; Chaoui, K.; Ronzier, E.; Lazar, I.; Bertrand-Michel, J.; Roques, V.; Balor, S.; Terce, F.; Lopez, A.; Salomé, L.; et al. Proteolipidic composition of exosomes changes during reticulocyte maturation. J. Biol. Chem. 2011, 286, 34426-34439. [CrossRef]

41. Bryk, A.H.; Wiśniewski, J.R. Quantitative Analysis of Human Red Blood Cell Proteome. J. Prot. Res. 2017, 16, 2752-2761. [CrossRef]

42. Leal, J.K.F.; Adjobo-Hermans, M.J.W.; Bosman, G.J.C.G.M. Red Blood Cell Homeostasis: Mechanisms and Effects of Microvesicle Generation in Health and Disease. Front. Physiol. 2018, 9, 703. [CrossRef] [PubMed]

43. Willekens, F.L.A.; Roerdinkholder-Stoelwinder, B.; Groenen-Döpp, Y.A.M.; Bos, H.J.; Bosman, G.J.C.G.M.; van den Bos, A.G.; Verkleij, A.J.; Werre, J.M. Hemoglobin loss from erythrocytes in vivo results from spleen-facilitated vesiculation. Blood 2003, 101, 747-751. [CrossRef] [PubMed]

44. Willekens, F.L.; Bosch, F.H.; Roerdinkholder-Stoelwinder, B.; Groenen-Döpp, Y.A.; Werre, J.M. Quantification of loss of haemoglobin components from the circulating red blood cell in vivo. Eur. J. Haematol. 1997, 58, 246-250. [CrossRef] [PubMed]

45. Willekens, F.L.A.; Werre, J.M.; Groenen-Döpp, Y.A.M.; Roerdinkholder-Stoelwinder, B.; de Pauw, B.; Bosman, G.J.C.G.M. Erythrocyte vesiculation: A self-protective mechanism? Br. J. Haematol. 2008, 141, 549-556. [CrossRef]

46. Bosman, G.J.C.G.M.; Lasonder, E.; Groenen-Döpp, Y.A.M.; Willekens, F.L.A.; Werre, J.M. The proteome of erythrocyte-derived microparticles from plasma: New clues for erythrocyte aging and vesiculation. J. Prot. 2012, 76, 203-210. [CrossRef]

47. Lux, S.E.T. Anatomy of the red cell membrane skeleton: Unanswered questions. Blood 2016, 127, 187-199. [CrossRef]

48. Ursitti, J.A.; Wade, J.B. Ultrastructure and immunocytochemistry of the isolated human erythrocyte membrane skeleton. Cell Motil. Cytoskeleton 1993, 25, 30-42. [CrossRef]

49. Liu, S.C.; Windisch, P.; Kim, S.; Palek, J. Oligomeric states of spectrin in normal erythrocyte membranes: Biochemical and electron microscopic studies. Cell 1984, 37, 587-594. [CrossRef]

50. Salomao, M.; An, X.; Guo, X.; Gratzer, W.B.; Mohandas, N.; Baines, A.J. Mammalian alpha I-spectrin is a neofunctionalized polypeptide adapted to small highly deformable erythrocytes. Proc. Natl. Acad. Sci. USA 2006, 103, 643-648. [CrossRef]

51. Picart, C.; Dalhaimer, P.; Discher, D.E. Actin protofilament orientation in deformation of the erythrocyte membrane skeleton. Biophys. J. 2000, 79, 2987-3000. [CrossRef]

52. An, X.; Salomao, M.; Guo, X.; Gratzer, W.; Mohandas, N. Tropomyosin modulates erythrocyte membrane stability. Blood 2007, 109, 1284-1288. [CrossRef] [PubMed]

53. Moyer, J.D.; Nowak, R.B.; Kim, N.E.; Larkin, S.K.; Peters, L.L.; Hartwig, J.; Kuypers, F.A.; Fowler, V.M. Tropomodulin 1-null mice have a mild spherocytic elliptocytosis with appearance of tropomodulin 3 in red blood cells and disruption of the membrane skeleton. Blood 2010, 116, 2590-2599. [CrossRef] [PubMed]

54. Li, X.; Matsuoka, Y.; Bennett, V. Adducin Preferentially Recruits Spectrin to the Fast Growing Ends of Actin Filaments in a Complex Requiring the MARCKS-related Domain and a Newly Defined Oligomerization Domain. J. Biol. Chem. 1998, 273, 19329-19338. [CrossRef] [PubMed]

55. Khan, A.A.; Hanada, T.; Mohseni, M.; Jeong, J.-J.; Zeng, L.; Gaetani, M.; Li, D.; Reed, B.C.; Speicher, D.W.; Chishti, A.H. Dematin and adducin provide a novel link between the spectrin cytoskeleton and human erythrocyte membrane by directly interacting with glucose transporter-1. J. Biol. Chem. 2008, 283, 14600-14609. [CrossRef]

56. Han, B.G.; Nunomura, W.; Takakuwa, Y.; Mohandas, N.; Jap, B.K. Protein 4.1R core domain structure and insights into regulation of cytoskeletal organization. Nat. Struct. Biol. 2000, 7, 871-875. [CrossRef]

57. Manno, S.; Takakuwa, Y.; Mohandas, N. Modulation of erythrocyte membrane mechanical function by protein 4.1 phosphorylation J. Biol. Chem. 2005, 280, 7581-7587. [CrossRef]

58. Low, P.S.; Willardson, B.M.; Mohandas, N.; Rossi, M.; Shohet, S. Contribution of the band 3-ankyrin interaction to erythrocyte membrane mechanical stability. Blood 1991, 77, 1581-1586. [CrossRef]

59. Westerman, M.; Pizzey, A.; Hirschman, J.; Cerino, M.; Weil-Weiner, Y.; Ramotar, P.; Eze, A.; Lawrie, A.; Purdy, G.; Mackie, I.; et al. Microvesicles in haemoglobinopathies offer insights into mechanisms of hypercoagulability, haemolysis and the effects of therapy. Br. J. Haematol. 2008, 142, 126-135. [CrossRef] 
60. Ferru, E.; Pantaleo, A.; Carta, F.; Mannu, F.; Khadjavi, A.; Gallo, V.; Ronzoni, L.; Graziadei, G.; Cappellini, M.D.; Turrini, F. Thalassemic erythrocytes release microparticles loaded with hemichromes by redox activation of p72Syk kinase. Haematologica 2014, 99, 570-578. [CrossRef]

61. Willekens, F.L.A.; Werre, J.M.; Kruijt, J.K.; Roerdinkholder-Stoelwinder, B.; Groenen-Döpp, Y.A.M.; van den Bos, A.G.; Bosman, G.J.C.G.M.; van Berkel, T.J.C. Liver Kupffer cells rapidly remove red blood cell-derived vesicles from the circulation by scavenger receptors. Blood 2005, 105, 2141-2145. [CrossRef]

62. Daleke, D.L. Regulation of phospholipid asymmetry in the erythrocyte membrane. Curr. Opin. Hematol. 2008, 15, 191-195. [CrossRef] [PubMed]

63. Said, A.S.; Rogers, S.C.; Doctor, A. Physiologic Impact of Circulating RBC Microparticles upon Blood-Vascular Interactions. Front. Physiol. 2017, 8, 1120. [CrossRef] [PubMed]

64. Gonzalez, L.J.; Gibbons, E.; Bailey, R.W.; Fairbourn, J.; Nguyen, T.; Smith, S.K.; Best, K.B.; Nelson, J.; Judd, A.M.; Bell, J.D. The influence of membrane physical properties on microvesicle release in human erythrocytes. PMC Biophys. $2009,2,7$. [CrossRef] [PubMed]

65. Nguyen, D.B.; Ly, T.B.T.; Wesseling, M.C.; Hittinger, M.; Torge, A.; Devitt, A.; Perrie, Y.; Bernhardt, I. Characterization of Microvesicles Released from Human Red Blood Cells. Cell. Physiol. Biochem. 2016, 38, 1085-1099. [CrossRef] [PubMed]

66. Wesseling, M.C.; Wagner-Britz, L.; Nguyen, D.B.; Asanidze, S.; Mutua, J.; Mohamed, N.; Hanf, B.; Ghashghaeinia, M.; Kaestner, L.; Bernhardt, I. Novel Insights in the Regulation of Phosphatidylserine Exposure in Human Red Blood Cells. Cell. Physiol. Biochem. 2016, 39, 1941-1954. [CrossRef]

67. Matte, A.; Bertoldi, M.; Mohandas, N.; An, X.; Bugatti, A.; Brunati, A.M.; Rusnati, M.; Tibaldi, E.; Siciliano, A.; Turrini, F.; et al. Membrane association of peroxiredoxin-2 in red cells is mediated by the N-terminal cytoplasmic domain of band 3. Free Radic. Biol. Med. 2013, 55, 27-35. [CrossRef] [PubMed]

68. Lang, F.; Gulbins, E.; Lerche, H.; Huber, S.M.; Kempe, D.S.; Foller, M. Eryptosis, a window to systemic disease. Cell. Physiol. Biochem. 2008, 22, 373-380. [CrossRef]

69. Salzer, U.; Hinterdorfer, P.; Hunger, U.; Borken, C.; Prohaska, R. Ca++-dependent vesicle release from erythrocytes involves stomatin-specific lipid rafts, synexin (annexin VII), and sorcin. Blood 2002, 99, 2569-2577. [CrossRef]

70. Wesseling, M.C.; Wagner-Britz, L.; Huppert, H.; Hanf, B.; Hertz, L.; Nguyen, D.B.; Bernhardt, I. Phosphatidylserine Exposure in Human Red Blood Cells Depending on Cell Age. Cell. Physiol. Biochem. 2016, 38, 1376-1390. [CrossRef]

71. Sudnitsyna, J.; Skverchinskaya, E.; Dobrylko, I.; Nikitina, E.; Gambaryan, S.; Mindukshev, I. Microvesicle Formation Induced by Oxidative Stress in Human Erythrocytes. Antioxidants 2020, 9, 929. [CrossRef]

72. Stowell, S.R.; Smith, N.H.; Zimring, J.C.; Fu, X.; Palmer, A.F.; Fontes, J.; Banerjee, U.; Yazer, M.H. Addition of ascorbic acid solution to stored murine red blood cells increases posttransfusion recovery and decreases microparticles and alloimmunization. Transfusion 2013, 53, 2248-2257. [CrossRef] [PubMed]

73. Kuo, L.; Freed, E.O. ARRDC1 as a mediator of microvesicle budding. Proc. Natl. Acad. Sci. USA 2012, 109, 4025-4026. [CrossRef] [PubMed]

74. Xu, B.; Fu, Y.; Liu, Y.; Agvanian, S.; Wirka, R.C.; Baum, R.; Zhou, K.; Shaw, R.M.; Hong, T. The ESCRT-III pathway facilitates cardiomyocyte release of cBIN1-containing microparticles. PLoS Biol. 2017, 15, e2002354. [CrossRef] [PubMed]

75. Li, B.; Antonyak, M.A.; Zhang, J.; Cerione, R.A. RhoA triggers a specific signaling pathway that generates transforming microvesicles in cancer cells. Oncogene 2012, 31, 4740-4749. [CrossRef] [PubMed]

76. Wilson, K.F.; Erickson, J.W.; Antonyak, M.A.; Cerione, R.A. Rho GTPases and their roles in cancer metabolism. Trends Mol. Med. 2013, 19, 74-82. [CrossRef]

77. Del Conde, I.; Shrimpton, C.N.; Thiagarajan, P.; López, J.A. Tissue-factor-bearing microvesicles arise from lipid rafts and fuse with activated platelets to initiate coagulation. Blood 2005, 106, 1604-1611. [CrossRef]

78. McConnell, R.E.; Higginbotham, J.N.; Shifrin, D.A., Jr.; Tabb, D.L.; Coffey, R.J.; Tyska, M.J. The enterocyte microvillus is a vesicle-generating organelle. J. Cell Biol. 2009, 185, 1285-1298. [CrossRef]

79. Kim, D.-K.; Lee, J.; Simpson, R.J.; Lötvall, J.; Gho, Y.S. EVpedia: A community web resource for prokaryotic and eukaryotic extracellular vesicles research. Semin. Cell Dev. Biol. 2015, 40, 4-7. [CrossRef]

80. Kalra, H.; Simpson, R.J.; Ji, H.; Aikawa, E.; Altevogt, P.; Askenase, P.; Bond, V.C.; Borràs, F.E.; Breakefield, X.; Budnik, V.; et al. Vesiclepedia: A compendium for extracellular vesicles with continuous community annotation. PLoS Biol. 2012, 10, e1001450. [CrossRef]

81. Kim, D.-K.; Kang, B.; Kim, O.Y.; Choi, D.-S.; Lee, J.; Kim, S.R.; Go, G.; Yoon, Y.J.; Kim, J.H.; Jang, S.C.; et al. EVpedia: An integrated database of high-throughput data for systemic analyses of extracellular vesicles. J. Extracell. Vesicles 2013, 2. [CrossRef]

82. Keerthikumar, S.; Chisanga, D.; Ariyaratne, D.; Al Saffar, H.; Anand, S.; Zhao, K.; Samuel, M.; Pathan, M.; Jois, M.; Chilamkurti, N.; et al. ExoCarta: A Web-Based Compendium of Exosomal Cargo. J. Mol. Biol. 2016, 428, 688-692. [CrossRef] [PubMed]

83. Prudent, M.; Delobel, J.; Hübner, A.; Benay, C.; Lion, N.; Tissot, J.-D. Proteomics of Stored Red Blood Cell Membrane and Storage-Induced Microvesicles Reveals the Association of Flotillin-2 With Band 3 Complexes. Front. Physiol. $2018,9,421$. [CrossRef] [PubMed]

84. Rubin, O.; Crettaz, D.; Canellini, G.; Tissot, J.D.; Lion, N. Microparticles in stored red blood cells: An approach using flow cytometry and proteomic tools. Vox Sang. 2008, 95, 288-297. [CrossRef] [PubMed] 
85. Antonelou, M.H.; Seghatchian, J. Update on extracellular vesicles inside red blood cell storage units: Adjust the sails closer to the new wind. Transfus. Apher. Sci. 2016, 55, 92-104. [CrossRef] [PubMed]

86. Tissot, J.-D.; Canellini, G.; Rubin, O.; Angelillo-Scherrer, A.; Delobel, J.; Prudent, M.; Lion, N. Blood microvesicles: From proteomics to physiology. Transl. Prot. 2013, 1, 38-52. [CrossRef]

87. Hamilton, A.J. MicroRNA in erythrocytes. Biochem. Soc. Trans. 2010, 38, 229-231. [CrossRef] [PubMed]

88. Aalto, A.P.; Pasquinelli, A.E. Small non-coding RNAs mount a silent revolution in gene expression. Curr. Opin. Cell Biol. 2012, 24, 333-340. [CrossRef]

89. Guerau-de-Arellano, M.; Alder, H.; Ozer, H.G.; Lovett-Racke, A.; Racke, M.K. miRNA profiling for biomarker discovery in multiple sclerosis: From microarray to deep sequencing. J. Neuroimmunol. 2012, 248, 32-39. [CrossRef]

90. Karius, T.; Schnekenburger, M.; Dicato, M.; Diederich, M. MicroRNAs in cancer management and their modulation by dietary agents. Biochem. Pharmacol. 2012, 83, 1591-1601. [CrossRef]

91. Saki, N.; Abroun, S.; Soleimani, M.; Hajizamani, S.; Shahjahani, M.; Kast, R.E.; Mortazavi, Y. Involvement of MicroRNA in T-Cell Differentiation and Malignancy. Int. J. Hematol. Oncol. Stem Cell Res. 2015, 9, 33-49.

92. Sun, L.; Yu, Y.; Niu, B.; Wang, D. Red Blood Cells as Potential Repositories of MicroRNAs in the Circulatory System. Front. Genet. 2020, 11, 442. [CrossRef] [PubMed]

93. Huang, H.; Zhu, J.; Fan, L.; Lin, Q.; Fu, D.; Wei, B.; Wei, S. MicroRNA Profiling of Exosomes Derived from Red Blood Cell Units: Implications in Transfusion-Related Immunomodulation. Biomed Res. Int. 2019, 2019, 2045915. [CrossRef] [PubMed]

94. Rasheed, Z.; Rasheed, N.; Abdulmonem, W.A.; Khan, M.I. Author Correction: MicroRNA-125b-5p regulates IL-1 $\beta$ induced inflammatory genes via targeting TRAF6-mediated MAPKs and NF- $\mathrm{KB}$ signaling in human osteoarthritic chondrocytes. Sci. Rep. 2019, 9, 14729. [CrossRef] [PubMed]

95. Diao, W.; Lu, L.; Li, S.; Chen, J.; Zen, K.; Li, L. MicroRNA-125b-5p modulates the inflammatory state of macrophages via targeting B7-H4. Biochem. Biophys. Res. Commun. 2017, 491, 912-918. [CrossRef]

96. Yang, D.; Yuan, Q.; Balakrishnan, A.; Bantel, H.; Klusmann, J.-H.; Manns, M.P.; Ott, M.; Cantz, T.; Sharma, A.D. MicroRNA-125b-5p mimic inhibits acute liver failure. Nat. Commun. 2016, 7, 11916. [CrossRef]

97. Morelli, E.; Leone, E.; Cantafio, M.E.G.; Di Martino, M.T.; Amodio, N.; Biamonte, L.; Gullà, A.; Foresta, U.; Pitari, M.R.; Botta, C.; et al. Selective targeting of IRF4 by synthetic microRNA-125b-5p mimics induces anti-multiple myeloma activity in vitro and in vivo. Leukemia 2015, 29, 2173-2183. [CrossRef]

98. Doss, J.F.; Corcoran, D.L.; Jima, D.D.; Telen, M.J.; Dave, S.S.; Chi, J.-T. A comprehensive joint analysis of the long and short RNA transcriptomes of human erythrocytes. BMC Genomics 2015, 16, 952. [CrossRef]

99. Dore, L.C.; Amigo, J.D.; Dos Santos, C.O.; Zhang, Z.; Gai, X.; Tobias, J.W.; Yu, D.; Klein, A.M.; Dorman, C.; Wu, W.; et al. A GATA-1-regulated microRNA locus essential for erythropoiesis. Proc. Natl. Acad. Sci. USA 2008, 105, 3333-3338. [CrossRef]

100. Sun, L.; Fan, F.; Li, R.; Niu, B.; Zhu, L.; Yu, S.; Wang, S.; Li, C.; Wang, D. Different Erythrocyte MicroRNA Profiles in Low- and High-Altitude Individuals. Front. Physiol. 2018, 9, 1099. [CrossRef]

101. Hua, Z.; Lv, Q.; Ye, W.; Wong, C.-K.A.; Cai, G.; Gu, D.; Ji, Y.; Zhao, C.; Wang, J.; Yang, B.B.; et al. MiRNA-directed regulation of VEGF and other angiogenic factors under hypoxia. PLoS ONE 2006, 1, e116. [CrossRef]

102. Kulshreshtha, R.; Ferracin, M.; Wojcik, S.E.; Garzon, R.; Alder, H.; Agosto-Perez, F.J.; Davuluri, R.; Liu, C.-G.; Croce, C.M.; Negrini, M.; et al. A microRNA signature of hypoxia. Mol. Cell. Biol. 2007, 27, 1859-1867. [CrossRef] [PubMed]

103. Piriyapongsa, J.; Jordan, I.K.; Conley, A.B.; Ronan, T.; Smalheiser, N.R. Transcription factor binding sites are highly enriched within microRNA precursor sequences. Biol. Direct 2011, 6, 61. [CrossRef] [PubMed]

104. Hebert, C.; Norris, K.; Scheper, M.A.; Nikitakis, N.; Sauk, J.J. High mobility group A2 is a target for miRNA-98 in head and neck squamous cell carcinoma. Mol. Cancer 2007, 6, 5. [CrossRef] [PubMed]

105. Juzenas, S.; Venkatesh, G.; Hübenthal, M.; Hoeppner, M.P.; Du, Z.G.; Paulsen, M.; Rosenstiel, P.; Senger, P.; Hofmann-Apitius, M.; Keller, A.; et al. A comprehensive, cell specific microRNA catalogue of human peripheral blood. Nucleic Acids Res. 2017, 45, 9290-9301. [CrossRef] [PubMed]

106. Eich, R.F.; Li, T.; Lemon, D.D.; Doherty, D.H.; Curry, S.R.; Aitken, J.F.; Mathews, A.J.; Johnson, K.A.; Smith, R.D.; Phillips, G.N., Jr.; et al. Mechanism of NO-induced oxidation of myoglobin and hemoglobin. Biochemistry 1996, 35, 69766983. [CrossRef] [PubMed]

107. Doherty, D.H.; Doyle, M.P.; Curry, S.R.; Vali, R.J.; Fattor, T.J.; Olson, J.S.; Lemon, D.D. Rate of reaction with nitric oxide determines the hypertensive effect of cell-free hemoglobin. Nat. Biotechnol. 1998, 16, 672-676. [CrossRef]

108. Donadee, C.; Raat, N.J.H.; Kanias, T.; Tejero, J.; Lee, J.S.; Kelley, E.E.; Zhao, X.; Liu, C.; Reynolds, H.; Azarov, I.; et al. Nitric Oxide Scavenging by Red Blood Cell Microparticles and Cell-Free Hemoglobin as a Mechanism for the Red Cell Storage Lesion. Circulation 2011, 124, 465-476. [CrossRef]

109. Liu, C.; Zhao, W.; Christ, G.J.; Gladwin, M.T.; Kim-Shapiro, D.B. Nitric oxide scavenging by red cell microparticles. Free Radic. Biol. Med. 2013, 65, 1164-1173. [CrossRef]

110. Herring, J.M.; McMichael, M.A.; Smith, S.A. Microparticles in health and disease. J. Vet. Intern. Med. 2013, 27, 1020-1033. [CrossRef]

111. Poisson, J.; Tanguy, M.; Davy, H.; Camara, F.; El Mdawar, M.B.; Kheloufi, M.; Dagher, T.; Devue, C.; Lasselin, J.; Plessier, A.; et al. Erythrocyte-derived microvesicles induce arterial spasms in JAK2V617F myeloproliferative neoplasm. J. Clin. Investig. 2020, 130, 2630-2643. [CrossRef] 
112. Harisa, G.I.; Badran, M.M.; Alanazi, F.K. Erythrocyte nanovesicles: Biogenesis, biological roles and therapeutic approach: Erythrocyte nanovesicles. Saudi Pharm. J. 2017, 25, 8-17. [CrossRef] [PubMed]

113. Kuhn, V.; Diederich, L.; Keller, T.C.S.t.; Kramer, C.M.; Lückstädt, W.; Panknin, C.; Suvorava, T.; Isakson, B.E.; Kelm, M.; CorteseKrott, M.M. Red Blood Cell Function and Dysfunction: Redox Regulation, Nitric Oxide Metabolism, Anemia. Antioxid. Redox Signal. 2017, 26, 718-742. [CrossRef] [PubMed]

114. Jank, H.; Salzer, U. Vesicles Generated during Storage of Red Blood Cells Enhance the Generation of Radical Oxygen Speciesin Activated Neutrophils. Sci. World J. 2011, 11, 173-185. [CrossRef]

115. Danesh, A.; Inglis, H.C.; Jackman, R.P.; Wu, S.; Deng, X.; Muench, M.O.; Heitman, J.W.; Norris, P.J. Exosomes from red blood cell units bind to monocytes and induce proinflammatory cytokines, boosting T-cell responses in vitro. Blood 2014, 123, 687-696. [CrossRef] [PubMed]

116. Hezel, M.E.V.; Nieuwland, R.; Bruggen, R.V.; Juffermans, N.P. The Ability of Extracellular Vesicles to Induce a Pro-Inflammatory Host Response. Int. J. Mol. Sci. 2017, 18, 1285. [CrossRef]

117. Almizraq, R.J.; Seghatchian, J.; Acker, J.P. Extracellular vesicles in transfusion-related immunomodulation and the role of blood component manufacturing. Transf. Apher. Sci. 2016, 55, 281-291. [CrossRef]

118. Wannez, A.; Devalet, B.; Chatelain, B.; Chatelain, C.; Dogné, J.-M.; Mullier, F. Extracellular Vesicles in Red Blood Cell Concentrates: An Overview. Transf. Med. Rev. 2019, 33, 125-130. [CrossRef]

119. Sadallah, S.; Eken, C.; Schifferli, J.A. Ectosomes as modulators of inflammation and immunity. Clin. Exp. Immunol. 2011, 163, 26-32. [CrossRef]

120. Straat, M.; van Hezel, M.E.; Böing, A.; Boer, A.T.-D.; Weber, N.; Nieuwland, R.; van Bruggen, R.; Juffermans, N.P. Monocytemediated activation of endothelial cells occurs only after binding to extracellular vesicles from red blood cell products, a process mediated by $\beta$-integrin. Transfusion 2016, 56, 3012-3020. [CrossRef]

121. Fischer, D.; Büssow, J.; Meybohm, P.; Weber, C.F.; Zacharowski, K.; Urbschat, A.; Müller, M.M.; Jennewein, C. Microparticles from stored red blood cells enhance procoagulant and proinflammatory activity. Transfusion 2017, 57, 2701-2711. [CrossRef]

122. Sadallah, S.; Eken, C.; Schifferli, J.A. Erythrocyte-derived ectosomes have immunosuppressive properties. J. Leukoc. Biol. 2008, 84, 1316-1325. [CrossRef] [PubMed]

123. Nazimek, K.; Bustos-Morán, E.; Blas-Rus, N.; Nowak, B.; Ptak, W.; Askenase, P.W.; Sánchez-Madrid, F.; Bryniarski, K. Syngeneic red blood cell-induced extracellular vesicles suppress delayed-type hypersensitivity to self-antigens in mice. Clin. Exp. Allergy 2019, 49, 1487-1499. [CrossRef] [PubMed]

124. Bradlow, B.A. Liberation of material with platelet-like coagulant properties from intact red cells and particularly from reticulocytes. Br. J. Haematol. 1961, 7, 476-495. [CrossRef] [PubMed]

125. Horne, M.K., 3rd; Cullinane, A.M.; Merryman, P.K.; Hoddeson, E.K. The effect of red blood cells on thrombin generation. Br. J. Haematol. 2006, 133, 403-408. [CrossRef]

126. Diamant, M.; Tushuizen, M.E.; Sturk, A.; Nieuwland, R. Cellular microparticles: New players in the field of vascular disease? Eur. J. Clin. Investig. 2004, 34, 392-401. [CrossRef]

127. Van Der Meijden, P.E.J.; Van Schilfgaarde, M.; Van Oerle, R.; Renné, T.; ten Cate, H.; Spronk, H.M.H. Platelet- and erythrocytederived microparticles trigger thrombin generation via factor XIIa. J. Thromb. Haemost. 2012, 10, 1355-1362. [CrossRef]

128. Koshiar, R.L.; Somajo, S.; Norstrom, E.; Dahlback, B. Erythrocyte-derived microparticles supporting activated protein C-mediated regulation of blood coagulation. PLoS ONE 2014, 9, e104200. [CrossRef]

129. Levin, G.; Sukhareva, E.; Lavrentieva, A. Impact of microparticles derived from erythrocytes on fibrinolysis. J. Thromb Thrombolysis 2016, 41, 452-458. [CrossRef]

130. Hashemi Tayer, A.; Amirizadeh, N.; Ahmadinejad, M.; Nikougoftar, M.; Deyhim, M.R.; Zolfaghari, S. Procoagulant Activity of Red Blood Cell-Derived Microvesicles during Red Cell Storage. Transfus. Med. Hemother. 2019, 46, 224-230. [CrossRef]

131. Tzounakas, V.L.; Georgatzakou, H.T.; Kriebardis, A.G.; Voulgaridou, A.I.; Stamoulis, K.E.; Foudoulaki-Paparizos, L.E.; Antonelou, M.H.; Papassideri, I.S. Donor variation effect on red blood cell storage lesion: A multivariable, yet consistent, story. Transfusion 2016, 56, 1274-1286. [CrossRef]

132. Sweeney, J.; Kouttab, N.; Kurtis, J. Stored red blood cell supernatant facilitates thrombin generation. Transfusion 2009, 49, 1569-1579. [CrossRef] [PubMed]

133. Rubin, O.; Delobel, J.; Prudent, M.; Lion, N.; Kohl, K.; Tucker, E.I.; Tissot, J.-D.; Angelillo-Scherrer, A. Red blood cell-derived microparticles isolated from blood units initiate and propagate thrombin generation. Transfusion 2013, 53, 1744-1754. [CrossRef] [PubMed]

134. Camus, S.M.; De Moraes, J.A.; Bonnin, P.; Abbyad, P.; Le Jeune, S.; Lionnet, F.; Loufrani, L.; Grimaud, L.; Lambry, J.-C.; Charue, D.; et al. Circulating cell membrane microparticles transfer heme to endothelial cells and trigger vasoocclusions in sickle cell disease. Blood 2015, 125, 3805-3814. [CrossRef] [PubMed]

135. Freedman, J.E.; Loscalzo, J. Nitric oxide and its relationship to thrombotic disorders: Nitric oxide and thrombotic disorders. J. Thromb. Haemost. 2003, 1, 1183-1188. [CrossRef]

136. Loscalzo, J. Nitric oxide insufficiency, platelet activation, and arterial thrombosis. Circ. Res. 2001, 88, 756-762. [CrossRef]

137. Devalet, B.; Mullier, F.; Chatelain, B.; Dogné, J.-M.; Chatelain, C. The central role of extracellular vesicles in the mechanisms of thrombosis in paroxysmal nocturnal haemoglobinuria: A review. J. Extracell Vesicles 2014, 3(1). [CrossRef] 
138. Yoshida, T.; Prudent, M.; D’Alessandro, A. Red blood cell storage lesion: Causes and potential clinical consequences. Blood Transfus. 2019, 17, 27-52. [CrossRef]

139. Macey, M.G.; Enniks, N.; Bevan, S. Flow cytometric analysis of microparticle phenotype and their role in thrombin generation. Cytometry B Clin. Cytom. 2011, 80, 57-63. [CrossRef]

140. Berckmans, R.J.; Nieuwland, R.; Böing, A.N.; Romijn, F.P.; Hack, C.E.; Sturk, A. Cell-derived microparticles circulate in healthy humans and support low grade thrombin generation. Thromb. Haemost. 2001, 85, 639-646.

141. Zubairova, L.D.; Nabiullina, R.M.; Nagaswami, C.; Zuev, Y.F.; Mustafin, I.G.; Litvinov, R.I.; Weisel, J.W. Circulating Microparticles Alter Formation, Structure, and Properties of Fibrin Clots. Sci. Rep. 2015, 5, 17611. [CrossRef]

142. Aharon, A.; Rebibo-Sabbah, A.; Tzoran, I.; Levin, C. Extracellular vesicles in hematological disorders. Rambam Maimonides Med. J. 2014, 5, e0032. [CrossRef] [PubMed]

143. Ataga, K.I. Hypercoagulability and thrombotic complications in hemolytic anemias. Haematologica 2009, 94, 1481-1484. [CrossRef] [PubMed]

144. Allan, D.; Limbrick, A.R.; Thomas, P.; Westerman, M.P. Release of spectrin-free spicules on reoxygenation of sickled erythrocytes. Nature 1982, 295, 612-613. [CrossRef] [PubMed]

145. Shet, A.S.; Aras, O.; Gupta, K.; Hass, M.J.; Rausch, D.J.; Saba, N.; Koopmeiners, L.; Key, N.S.; Hebbel, R.P. Sickle blood contains tissue factor-positive microparticles derived from endothelial cells and monocytes. Blood 2003, 102, 2678-2683. [CrossRef] [PubMed]

146. van Beers, E.J.; Schaap, M.C.L.; Berckmans, R.J.; Nieuwland, R.; Sturk, A.; van Doormaal, F.F.; Meijers, J.C.M.; Biemond, B.J.; group, C.S. Circulating erythrocyte-derived microparticles are associated with coagulation activation in sickle cell disease. Haematologica 2009, 94, 1513-1519. [CrossRef]

147. Gerotziafas, G.T.; Van Dreden, P.; Chaari, M.; Galea, V.; Khaterchi, A.; Lionnet, F.; Stankovic-Stojanovic, K.; Blanc-Brude, O.; Woodhams, B.; Maier-Redelsperger, M.; et al. The acceleration of the propagation phase of thrombin generation in patients with steady-state sickle cell disease is associated with circulating erythrocyte-derived microparticles. Thromb. Haemost. 2012, 107, 1044-1052. [CrossRef]

148. Mahfoudhi, E.; Lecluse, Y.; Driss, F.; Abbes, S.; Flaujac, C.; Garçon, L. Red cells exchanges in sickle cells disease lead to a selective reduction of erythrocytes-derived blood microparticles. Br. J. Haematol. 2012, 156, 545-547. [CrossRef]

149. Tantawy, A.A.G.; Adly, A.A.M.; Ismail, E.A.R.; Habeeb, N.M.; Farouk, A. Circulating platelet and erythrocyte microparticles in young children and adolescents with sickle cell disease: Relation to cardiovascular complications. Platelets 2013, 24, 605614. [CrossRef]

150. Nebor, D.; Bowers, A.; Connes, P.; Hardy-Dessources, M.-D.; Knight-Madden, J.; Cumming, V.; Reid, M.; Romana, M. Plasma concentration of platelet-derived microparticles is related to painful vaso-occlusive phenotype severity in sickle cell anemia. PLoS ONE 2014, 9, e87243. [CrossRef]

151. Kasar, M.; Boğa, C.; Yeral, M.; Asma, S.; Kozanoglu, I.; Ozdogu, H. Clinical significance of circulating blood and endothelial cell microparticles in sickle-cell disease. J. Thromb. Thrombolysis 2014, 38, 167-175. [CrossRef]

152. Piccin, A.; Murphy, C.; Eakins, E.; Kunde, J.; Corvetta, D.; Di Pierro, A.; Negri, G.; Guido, M.; Sainati, L.; Mc Mahon, C.; et al. Circulating microparticles, protein $\mathrm{C}$, free protein $\mathrm{S}$ and endothelial vascular markers in children with sickle cell anaemia. $J$. Extracell Vesicles 2015, 4, 28414. [CrossRef] [PubMed]

153. Hierso, R.; Lemonne, N.; Villaescusa, R.; Lalanne-Mistrih, M.-L.; Charlot, K.; Etienne-Julan, M.; Tressières, B.; Lamarre, Y.; Tarer, V.; Garnier, Y.; et al. Exacerbation of oxidative stress during sickle vaso-occlusive crisis is associated with decreased anti-band 3 autoantibodies rate and increased red blood cell-derived microparticle level: A prospective study. Br. J. Haematol. 2017, 176, 805-813. [CrossRef] [PubMed]

154. Nébor, D.; Romana, M.; Santiago, R.; Vachiery, N.; Picot, J.; Broquere, C.; Chaar, V.; Doumdo, L.; Odièvre, M.-H.; Benkerrou, M.; et al. Fetal hemoglobin and hydroxycarbamide moduate both plasma concentration and cellular origin of circulating microparticles in sickle cell anemia children. Haematologica 2013, 98, 862-867. [CrossRef] [PubMed]

155. Garnier, Y.; Ferdinand, S.; Etienne-Julan, M.; Elana, G.; Petras, M.; Doumdo, L.; Tressières, B.; Lalanne-Mistrih, M.-L.; HardyDessources, M.-D.; Connes, P.; et al. Differences of microparticle patterns between sickle cell anemia and hemoglobin SC patients. PLoS ONE 2017, 12, e0177397. [CrossRef]

156. Romana, M.; Connes, P.; Key, N.S. Microparticles in sickle cell disease. Clin. Hemorheol. Microcirc. 2018, 68, 319-329. [CrossRef]

157. Taher, A.T.; Otrock, Z.K.; Uthman, I.; Cappellini, M.D. Thalassemia and hypercoagulability. Blood Rev. 2008, 22, 283-292. [CrossRef]

158. Musallam, K.M.; Taher, A.T. Thrombosis in thalassemia: Why are we so concerned? Hemoglobin 2011, 35, 503-510. [CrossRef]

159. Pattanapanyasat, K.; Gonwong, S.; Chaichompoo, P.; Noulsri, E.; Lerdwana, S.; Sukapirom, K.; Siritanaratkul, N.; Fucharoen, S. Activated platelet-derived microparticles in thalassaemia. Br. J. Haematol. 2007, 136, 462-471. [CrossRef]

160. Pattanapanyasat, K.; Noulsri, E.; Fucharoen, S.; Lerdwana, S.; Lamchiagdhase, P.; Siritanaratkul, N.; Webster, H.K. Flow cytometric quantitation of red blood cell vesicles in thalassemia. Cytometry B Clin. Cytom. 2004, 57, 23-31. [CrossRef]

161. Habib, A.; Kunzelmann, C.; Shamseddeen, W.; Zobairi, F.; Freyssinet, J.-M.; Taher, A. Elevated levels of circulating procoagulant microparticles in patients with beta-thalassemia intermedia. Haematologica 2008, 93, 941-942. [CrossRef]

162. Chaichompoo, P.; Kumya, P.; Khowawisetsut, L.; Chiangjong, W.; Chaiyarit, S.; Pongsakul, N.; Sirithanaratanakul, N.; Fucharoen, S.; Thongboonkerd, V.; Pattanapanyasat, K. Characterizations and proteome analysis of platelet-free plasma-derived microparticles in $\beta$-thalassemia/hemoglobin E patients. J. Proteomics 2012, 76, 239-250. [CrossRef] [PubMed] 
163. Agouti, I.; Cointe, S.; Robert, S.; Judicone, C.; Loundou, A.; Driss, F.; Brisson, A.; Steschenko, D.; Rose, C.; Pondarré, C.; et al. Platelet and not erythrocyte microparticles are procoagulant in transfused thalassaemia major patients. Br. J. Haematol. 2015, 171, 615-624. [CrossRef] [PubMed]

164. Tantawy, A.A.G.; Adly, A.A.M.; Ismail, E.A.R.; Habeeb, N.M. Flow cytometric assessment of circulating platelet and erythrocytes microparticles in young thalassemia major patients: Relation to pulmonary hypertension and aortic wall stiffness. Eur. J. Haematol. 2013, 90, 508-518. [CrossRef] [PubMed]

165. Kheansaard, W.; Phongpao, K.; Paiboonsukwong, K.; Pattanapanyasat, K.; Chaichompoo, P.; Svasti, S. Microparticles from $\beta$-thalassaemia/HbE patients induce endothelial cell dysfunction. Sci. Rep. 2018, 8, 13033. [CrossRef]

166. Tripodi, A.; Cappellini, M.D.; Chantarangkul, V.; Padovan, L.; Fasulo, M.R.; Marcon, A.; Mannucci, P.M. Hypercoagulability in splenectomized thalassemic patients detected by whole-blood thromboelastometry, but not by thrombin generation in platelet-poor plasma. Haematologica 2009, 94, 1520-1527. [CrossRef]

167. Peacock-Young, B.; Macrae, F.L.; Newton, D.J.; Hill, A.; Ariëns, R.A.S. The prothrombotic state in paroxysmal nocturnal hemoglobinuria: A multifaceted source. Haematologica 2018, 103, 9-17. [CrossRef]

168. Hill, A.; Kelly, R.J.; Hillmen, P. Thrombosis in paroxysmal nocturnal hemoglobinuria. Blood 2013, 121, 4985-4996. [CrossRef]

169. Kozuma, Y.; Sawahata, Y.; Takei, Y.; Chiba, S.; Ninomiya, H. Procoagulant properties of microparticles released from red blood cells in paroxysmal nocturnal haemoglobinuria. Br. J. Haematol. 2011, 152, 631-639. [CrossRef]

170. Hugel, B.; Socié, G.; Vu, T.; Toti, F.; Gluckman, E.; Freyssinet, J.M.; Scrobohaci, M.L. Elevated levels of circulating procoagulant microparticles in patients with paroxysmal nocturnal hemoglobinuria and aplastic anemia. Blood 1999, 93, 3451-3456. [CrossRef]

171. Simak, J.; Holada, K.; Risitano, A.M.; Zivny, J.H.; Young, N.S.; Vostal, J.G. Elevated circulating endothelial membrane microparticles in paroxysmal nocturnal haemoglobinuria. Br. J. Haematol. 2004, 125, 804-813. [CrossRef]

172. Ovchynnikova, E.; Aglialoro, F.; von Lindern, M.; van den Akker, E. The Shape Shifting Story of Reticulocyte Maturation. Front. Physiol. 2018, 9, 829. [CrossRef] [PubMed]

173. Mankelow, T.J.; Griffiths, R.E.; Trompeter, S.; Flatt, J.F.; Cogan, N.M.; Massey, E.J.; Anstee, D.J. Autophagic vesicles on mature human reticulocytes explain phosphatidylserine-positive red cells in sickle cell disease. Blood 2015, 126, 1831-1834. [CrossRef] [PubMed]

174. Kalluri, R. The biology and function of exosomes in cancer. J. Clin. Investig. 2016, 126, 1208-1215. [CrossRef] [PubMed]

175. Fitts, C.A.; Ji, N.; Li, Y.; Tan, C. Exploiting Exosomes in Cancer Liquid Biopsies and Drug Delivery. Adv. Healthc. Mater. 2019, 8, e1801268. [CrossRef] [PubMed]

176. Zhang, Y.; Hu, Y.-W.; Zheng, L.; Wang, Q. Characteristics and Roles of Exosomes in Cardiovascular Disease. DNA Cell Biol. 2017, 36, 202-211. [CrossRef]

177. Jansen, F.; Li, Q. Exosomes as Diagnostic Biomarkers in Cardiovascular Diseases. Exosomes Cardiovasc. Dis. 2017, 998, 6170. [CrossRef]

178. Kanninen, K.M.; Bister, N.; Koistinaho, J.; Malm, T. Exosomes as new diagnostic tools in CNS diseases. Biochim. Biophys. Acta (BBA) Mol. Basis Dis. 2016, 1862, 403-410. [CrossRef]

179. Alipoor, S.D.; Mortaz, E.; Garssen, J.; Movassaghi, M.; Mirsaeidi, M.; Adcock, I.M. Exosomes and Exosomal miRNA in Respiratory Diseases. Med. Inflamm. 2016, 2016, 1-11. [CrossRef]

180. Masyuk, A.I.; Masyuk, T.V.; LaRusso, N.F. Exosomes in the pathogenesis, diagnostics and therapeutics of liver diseases. J. Hepatol. 2013, 59, 621-625. [CrossRef]

181. Zhang, W.; Zhou, X.; Zhang, H.; Yao, Q.; Liu, Y.; Dong, Z. Extracellular vesicles in diagnosis and therapy of kidney diseases. Am. J. Physiol. Renal Physiol. 2016, 311, F844-F851. [CrossRef]

182. Katakowski, M.; Buller, B.; Zheng, X.; Lu, Y.; Rogers, T.; Osobamiro, O.; Shu, W.; Jiang, F.; Chopp, M. Exosomes from marrow stromal cells expressing miR-146b inhibit glioma growth. Cancer Lett. 2013, 335, 201-204. [CrossRef] [PubMed]

183. Ohno, S.-I.; Takanashi, M.; Sudo, K.; Ueda, S.; Ishikawa, A.; Matsuyama, N.; Fujita, K.; Mizutani, T.; Ohgi, T.; Ochiya, T.; et al. Systemically injected exosomes targeted to EGFR deliver antitumor microRNA to breast cancer cells. Mol. Ther. 2013, 21, 185-191. [CrossRef] [PubMed]

184. Kamerkar, S.; LeBleu, V.S.; Sugimoto, H.; Yang, S.; Ruivo, C.F.; Melo, S.A.; Lee, J.J.; Kalluri, R. Exosomes facilitate therapeutic targeting of oncogenic KRAS in pancreatic cancer. Nature 2017, 546, 498-503. [CrossRef] [PubMed]

185. Mendt, M.; Kamerkar, S.; Sugimoto, H.; McAndrews, K.M.; Wu, C.-C.; Gagea, M.; Yang, S.; Rodriges Blanko, E.V.; Peng, Q.; Ma, X.; et al. Generation and testing of clinical-grade exosomes for pancreatic cancer. JCI Insight 2018, 3, e99263. [CrossRef] [PubMed]

186. Shi, J.; Kundrat, L.; Pishesha, N.; Bilate, A.; Theile, C.; Maruyama, T.; Dougan, S.K.; Ploegh, H.L.; Lodish, H.F. Engineered red blood cells as carriers for systemic delivery of a wide array of functional probes. Proc. Natl. Acad. Sci. USA 2014, 111, 10131-10136. [CrossRef]

187. Usman, W.M.; Pham, T.C.; Kwok, Y.Y.; Vu, L.T.; Ma, V.; Peng, B.; Chan, Y.S.; Wei, L.; Chin, S.M.; Azad, A.; et al. Efficient RNA drug delivery using red blood cell extracellular vesicles. Nat. Commun. 2018, 9, 2359. [CrossRef]

188. Malhotra, S.; Dumoga, S.; Sirohi, P.; Singh, N. Red Blood Cells-Derived Vesicles for Delivery of Lipophilic Drug Camptothecin. ACS Appl. Mater. Interfaces 2019, 11, 22141-22151. [CrossRef] 
189. Chang, M.; Hsiao, J.-K.; Yao, M.; Chien, L.-Y.; Hsu, S.-C.; Ko, B.-S.; Chen, S.-T.; Liu, H.-M.; Chen, Y.-C.; Yang, C.-S.; et al. Homologous RBC-derived vesicles as ultrasmall carriers of iron oxide for magnetic resonance imaging of stem cells. Nanotechnology 2010, 21, 235103. [CrossRef]

190. Gangadaran, P.; Hong, C.M.; Oh, J.M.; Rajendran, R.L.; Kalimuthu, S.; Son, S.H.; Gopal, A.; Zhu, L.; Baek, S.H.; Jeong, S.Y.; et al. In vivo Non-invasive Imaging of Radio-Labeled Exosome-Mimetics Derived from Red Blood Cells in Mice. Front. Pharmacol. 2018, 9, 817. [CrossRef]

191. Iwamoto, T. Clinical Application of Drug Delivery Systems in Cancer Chemotherapy: Review of the Efficacy and Side Effects of Approved Drugs. Biol. Pharm. Bull. 2013, 36, 715-718. [CrossRef]

192. Veronese, F.M.; Pasut, G. PEGylation, successful approach to drug delivery. Drug Discov. Today 2005, 10, 1451-1458. [CrossRef]

193. Harris, J.M.; Chess, R.B. Effect of pegylation on pharmaceuticals. Nat. Rev. Drug Discov. 2003, 2, 214-221. [CrossRef] [PubMed]

194. Ihler, G.M.; Glew, R.H.; Schnure, F.W. Enzyme Loading of Erythrocytes. Proc. Natl. Acad. Sci. USA 1973, 70, 2663-2666. [CrossRef] [PubMed]

195. Pierigè, F.; Serafini, S.; Rossi, L.; Magnani, M. Cell-based drug delivery. Adv. Drug Deliv. Rev. 2008, 60, 286-295. [CrossRef] [PubMed]

196. Hamidi, M.; Tajerzadeh, H. Carrier Erythrocytes: An Overview. Drug Deliv. 2003, 10, 9-20. [CrossRef]

197. Dehaini, D.; Wei, X.; Fang, R.H.; Masson, S.; Angsantikul, P.; Luk, B.T.; Zhang, Y.; Ying, M.; Jiang, Y.; Kroll, A.V.; et al. ErythrocytePlatelet Hybrid Membrane Coating for Enhanced Nanoparticle Functionalization. Adv. Mater. 2017, 29, 1606209. [CrossRef]

198. Yoo, J.-W.; Irvine, D.J.; Discher, D.E.; Mitragotri, S. Bio-inspired, bioengineered and biomimetic drug delivery carriers. Nat. Rev. Drug Discov. 2011, 10, 521-535. [CrossRef]

199. Doshi, N.; Zahr, A.S.; Bhaskar, S.; Lahann, J.; Mitragotri, S. Red blood cell-mimicking synthetic biomaterial particles. Proc. Natl. Acad. Sci. USA 2009, 106, 21495-21499. [CrossRef]

200. Tsai, R.K.; Rodriguez, P.L.; Discher, D.E. Self inhibition of phagocytosis: The affinity of 'marker of self' CD47 for SIRP $\alpha$ dictates potency of inhibition but only at low expression levels. Blood Cells Mol. Dis. 2010, 45, 67-74. [CrossRef]

201. Barclay, A.N.; Van den Berg, T.K. The Interaction Between Signal Regulatory Protein Alpha (SIRP $\alpha$ ) and CD47: Structure, Function, and Therapeutic Target. Annu. Rev. Immunol. 2014, 32, 25-50. [CrossRef]

202. Schönermark, S.; Rauterberg, E.W.; Shin, M.L.; Löke, S.; Roelcke, D.; Hänsch, G.M. Homologous species restriction in lysis of human erythrocytes: A membrane-derived protein with C8-binding capacity functions as an inhibitor. J. Immunol. 1986, 136, 1772-1776. [PubMed]

203. Zalman, L.S.; Wood, L.M.; Müller-Eberhard, H.J. Isolation of a human erythrocyte membrane protein capable of inhibiting expression of homologous complement transmembrane channels. Proc. Natl. Acad. Sci. USA 1986, 83, 6975-6979. [CrossRef] [PubMed]

204. Kim, D.D.; Miwa, T.; Kimura, Y.; Schwendener, R.A.; van Lookeren Campagne, M.; Song, W.-C. Deficiency of decay-accelerating factor and complement receptor 1-related gene/protein y on murine platelets leads to complement-dependent clearance by the macrophage phagocytic receptor CRIg. Blood 2008, 112, 1109-1119. [CrossRef] [PubMed]

205. Fang, R.H.; Hu, C.-M.J.; Zhang, L. Nanoparticles disguised as red blood cells to evade the immune system. Expert Opin. Biol. Therapy 2012, 12, 385-389. [CrossRef] [PubMed]

206. Hu, C.-M.J.; Zhang, L.; Aryal, S.; Cheung, C.; Fang, R.H.; Zhang, L. Erythrocyte membrane-camouflaged polymeric nanoparticles as a biomimetic delivery platform. Proc. Natl. Acad. Sci. USA 2011, 108, 10980-10985. [CrossRef]

207. Tajerzadeh, H.; Hamidi, M. Evaluation of hypotonic preswelling method for encapsulation of enalaprilat in intact human erythrocytes. Drug Dev. Ind. Pharm. 2000, 26, 1247-1257. [CrossRef]

208. Lynch, A.L.; Chen, R.; Slater, N.K.H. pH-responsive polymers for trehalose loading and desiccation protection of human red blood cells. Biomaterials 2011, 32, 4443-4449. [CrossRef]

209. Ren, X.; Zheng, R.; Fang, X.; Wang, X.; Zhang, X.; Yang, W.; Sha, X. Red blood cell membrane camouflaged magnetic nanoclusters for imaging-guided photothermal therapy. Biomaterials 2016, 92, 13-24. [CrossRef]

210. Luk, B.T.; Hu, C.-M.J.; Fang, R.H.; Dehaini, D.; Carpenter, C.; Gao, W.; Zhang, L. Interfacial interactions between natural RBC membranes and synthetic polymeric nanoparticles. Nanoscale 2014, 6, 2730-2737. [CrossRef]

211. Xia, Q.; Zhang, Y.; Li, Z.; Hou, X.; Feng, N. Red blood cell membrane-camouflaged nanoparticles: A novel drug delivery system for antitumor application. Acta Pharm. Sin. B 2019, 9, 675-689. [CrossRef]

212. Miyazaki, J.-I.; Aihara, H. Gene Transfer into Muscle by Electroporation In Vivo. Gene Therapy Protocols 1998, 69, 49-62. [CrossRef]

213. Zhang, J.; Gao, W.; Fang, R.H.; Dong, A.; Zhang, L. Synthesis of Nanogels via Cell Membrane-Templated Polymerization. Small 2015, 11, 4309-4313. [CrossRef] [PubMed]

214. Su, J.; Sun, H.; Meng, Q.; Yin, Q.; Tang, S.; Zhang, P.; Chen, Y.; Zhang, Z.; Yu, H.; Li, Y. Long Circulation Red-Blood-Cell-Mimetic Nanoparticles with Peptide-Enhanced Tumor Penetration for Simultaneously Inhibiting Growth and Lung Metastasis of Breast Cancer. Adv. Funct. Mater. 2016, 26, 1243-1252. [CrossRef]

215. Martinive, P.; De Wever, J.; Bouzin, C.; Baudelet, C.; Sonveaux, P.; Grégoire, V.; Gallez, B.; Feron, O. Reversal of temporal and spatial heterogeneities in tumor perfusion identifies the tumor vascular tone as a tunable variable to improve drug delivery. Mol. Cancer Ther. 2006, 5, 1620-1627. [CrossRef]

216. Sonveaux, P.; Dessy, C.; Martinive, P.; Havaux, X.; Jordan, B.F.; Gallez, B.; Grégoire, V.; Balligand, J.-L.; Feron, O. Endothelin-1 is a critical mediator of myogenic tone in tumor arterioles: Implications for cancer treatment. Cancer Res. 2004, 64, 32093214. [CrossRef] 
217. Hamid, Z.A.A.; Abdul Hamid, Z.A.; Tham, C.Y.; Ahmad, Z. Preparation and optimization of surface-engineered poly(lactic acid) microspheres as a drug delivery device. J. Mater. Sci. 2018, 53, 4745-4758. [CrossRef]

218. Shive, M.S.; Anderson, J.M. Biodegradation and biocompatibility of PLA and PLGA microspheres. Adv. Drug Deliv. Rev. 1997, 28, 5-24. [CrossRef]

219. McCall, R.L.; Sirianni, R.W. PLGA Nanoparticles Formed by Single- or Double-emulsion with Vitamin E-TPGS. J. Visualized Exp. 2013, 82, 51015. [CrossRef]

220. Fang, R.H.; Hu, C.-M.J.; Luk, B.T.; Gao, W.; Copp, J.A.; Tai, Y.; O'Connor, D.E.; Zhang, L. Cancer cell membrane-coated nanoparticles for anticancer vaccination and drug delivery. Nano Lett. 2014, 14, 2181-2188. [CrossRef]

221. Lin, H.J.; Wang, J.H.; Wang, C.Y.; Wu, Y.C. The preparation and characteristic of poly(lactide co-glycolide) microspheres as novel antigen delivery systems. Int. J. Nanotechnol. 2013, 10, 870. [CrossRef]

222. Xing, L.; Shi, Q.; Zheng, K.; Shen, M.; Ma, J.; Li, F.; Liu, Y.; Lin, L.; Tu, W.; Duan, Y.; et al. Ultrasound-Mediated Microbubble Destruction (UMMD) Facilitates the Delivery of CA19-9 Targeted and Paclitaxel Loaded mPEG-PLGA-PLL Nanoparticles in Pancreatic Cancer. Theranostics 2016, 6, 1573-1587. [CrossRef] [PubMed]

223. Hao, R.; Xing, R.; Xu, Z.; Hou, Y.; Gao, S.; Sun, S. ChemInform Abstract: Synthesis, Functionalization, and Biomedical Applications of Multifunctional Magnetic Nanoparticles. Chem. Inform. 2010, 41. [CrossRef]

224. Sharifi, S.; Seyednejad, H.; Laurent, S.; Atyabi, F.; Saei, A.A.; Mahmoudi, M. Superparamagnetic iron oxide nanoparticles forin vivomolecular and cellular imaging. Contrast Med. Mol. Imaging 2015, 10, 329-355. [CrossRef] [PubMed]

225. Yoshida , T.; Sasayama , T.; Enpuku , K. (Invited) Biological Applications of Magnetic Nanoparticles for Magnetic Immunoassay and Magnetic Particle Imaging. ECS Meet. Abstr. 2016. [CrossRef]

226. Chu, M.; Shao, Y.; Peng, J.; Dai, X.; Li, H.; Wu, Q.; Shi, D. Near-infrared laser light mediated cancer therapy by photothermal effect of Fe3O4 magnetic nanoparticles. Biomaterials 2013, 34, 4078-4088. [CrossRef]

227. Chen, H.; Burnett, J.; Zhang, F.; Zhang, J.; Paholak, H.; Sun, D. Highly crystallized iron oxide nanoparticles as effective and biodegradable mediators for photothermal cancer therapy. J. Mater. Chem. B Mater. Biol. Med. 2014, 2, 757-765. [CrossRef]

228. Shen, S.; Wang, S.; Zheng, R.; Zhu, X.; Jiang, X.; Fu, D.; Yang, W. Magnetic nanoparticle clusters for photothermal therapy with near-infrared irradiation. Biomaterials 2015, 39, 67-74. [CrossRef]

229. Su, J.; Sun, H.; Meng, Q.; Zhang, P.; Yin, Q.; Li, Y. Enhanced Blood Suspensibility and Laser-Activated Tumor-specific Drug Release of Theranostic Mesoporous Silica Nanoparticles by Functionalizing with Erythrocyte Membranes. Theranostics 2017, 7, 523-537. [CrossRef]

230. Zhou, Y.; Quan, G.; Wu, Q.; Zhang, X.; Niu, B.; Wu, B.; Huang, Y.; Pan, X.; Wu, C. Mesoporous silica nanoparticles for drug and gene delivery. Acta Pharm. Sin. B 2018, 8, 165-177. [CrossRef]

231. Cheng, L.; Yang, K.; Li, Y.; Chen, J.; Wang, C.; Shao, M.; Lee, S.-T.; Liu, Z. Facile preparation of multifunctional upconversion nanoprobes for multimodal imaging and dual-targeted photothermal therapy. Angew. Chem. Int. Ed. Engl. 2011, 50, 73857390. [CrossRef]

232. Rieffel, J.; Chen, F.; Kim, J.; Chen, G.; Shao, W.; Shao, S.; Chitgupi, U.; Hernandez, R.; Graves, S.A.; Nickles, R.J.; et al. Hexamodal imaging with porphyrin-phospholipid-coated upconversion nanoparticles. Adv. Mater. 2015, 27, 1785-1790. [CrossRef] [PubMed]

233. Chen, Z.; Liu, Z.; Li, Z.; Ju, E.; Gao, N.; Zhou, L.; Ren, J.; Qu, X. Upconversion nanoprobes for efficiently in vitro imaging reactive oxygen species and in vivo diagnosing rheumatoid arthritis. Biomaterials 2015, 39, 15-22. [CrossRef] [PubMed]

234. Zhang, F.; Braun, G.B.; Shi, Y.; Zhang, Y.; Sun, X.; Reich, N.O.; Zhao, D.; Stucky, G. Fabrication of Ag@SiO(2)@Y(2)O(3):Er nanostructures for bioimaging: Tuning of the upconversion fluorescence with silver nanoparticles. J. Am. Chem. Soc. 2010, 132, 2850-2851. [CrossRef] [PubMed]

235. Li, J.; Huang, J.; Ao, Y.; Li, S.; Miao, Y.; Yu, Z.; Zhu, L.; Lan, X.; Zhu, Y.; Zhang, Y.; et al. Synergizing Upconversion Nanophotosensitizers with Hyperbaric Oxygen to Remodel the Extracellular Matrix for Enhanced Photodynamic Cancer Therapy. ACS Appl. Mater. Interfaces 2018, 10, 22985-22996. [CrossRef]

236. Giljohann, D.A.; Seferos, D.S.; Daniel, W.L.; Massich, M.D.; Patel, P.C.; Mirkin, C.A. Gold Nanoparticles for Biology and Medicine. Angew. Chem. Int. Ed. 2010, 49, 3280-3294. [CrossRef]

237. Piao, J.-G.; Wang, L.; Gao, F.; You, Y.-Z.; Xiong, Y.; Yang, L. Erythrocyte membrane is an alternative coating to polyethylene glycol for prolonging the circulation lifetime of gold nanocages for photothermal therapy. ACS Nano 2014, 8, 10414-10425. [CrossRef]

238. Toth, M.; Fridman, R. Assessment of Gelatinases (MMP-2 and MMP-9) by Gelatin Zymography. Metastasis Res. Protocols 2012, 163-174. [CrossRef]

239. Li, L.-L.; Xu, J.-H.; Qi, G.-B.; Zhao, X.; Yu, F.; Wang, H. Core-Shell Supramolecular Gelatin Nanoparticles for Adaptive and "On-Demand" Antibiotic Delivery. ACS Nano 2014, 8, 4975-4983. [CrossRef]

240. Castro, F.; Martins, C.; Silveira, M.J.; Moura, R.P.; Pereira, C.L.; Sarmento, B. Advances on erythrocyte-mimicking nanovehicles to overcome barriers in biological microenvironments. Adv. Drug Deliv. Rev. 2020. [CrossRef] 